\title{
PREVAILING WIND DIRECTIONS IN THE ARCTIC OCEAN
}

\author{
Michael A. Bilello
}

March 1973

\author{
PREPARED FOR \\ ADVANCED RESEARCH PROJECTS AGENCY \\ ARPA ORDER 1615 \\ BY \\ CORPS OF ENGINEERS, U.S. ARMY \\ COLD REGIONS RESEARCH AND ENGINEERING LABORATORY \\ HANOVER, NEW HAMPSHIRE
}




\section{PREF ACE}

This report was prepared by Michael A. Bilello, Research Meteorologist, of the Snow and Ice Branch, Research Division, USA CRREL. The report was published as part of the Arctic Surface Effect Vehicle program of the Advanced Research Projects Agency under ARPA Order 1615.

The author wishes to express appreciation to Dr. K.F. Sterrett for his guidance throughout the study, and to Mr. J.R. Hicks, Dr. C.C. Langway, Jr., and Dr. J.W. Weertman for their technical review of the paper. Mr. Roy Bates, USA CRREL, assisted with the (computation and tabulation of the data for Part $I$. 


\section{CONTENTS}

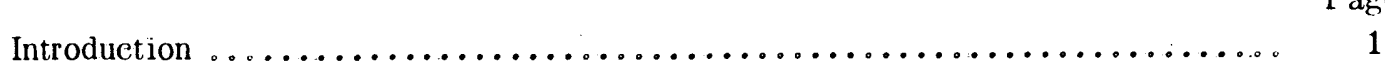

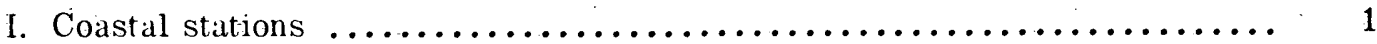

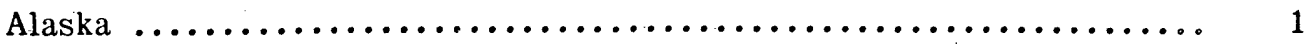

Canada ................................................. 1

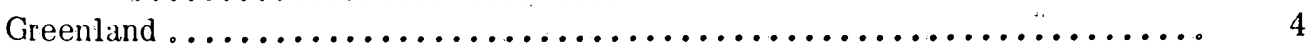

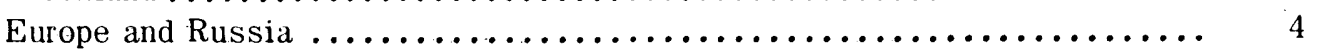

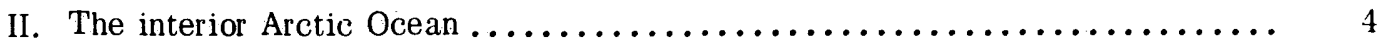

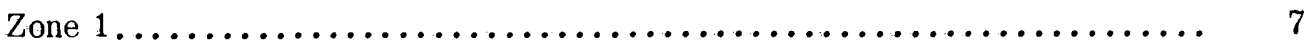

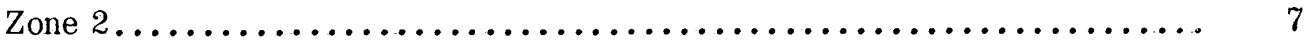

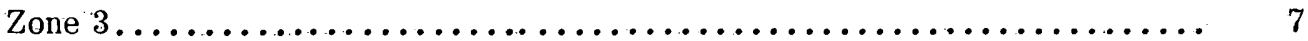

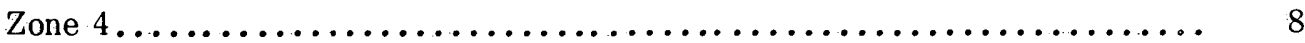

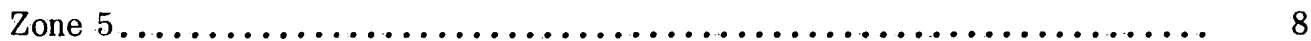

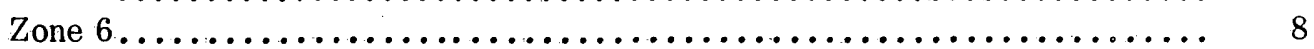

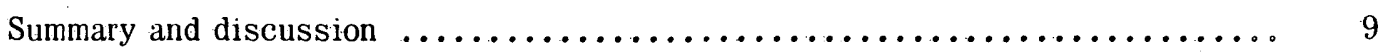

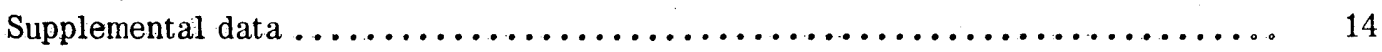

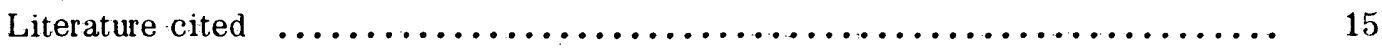

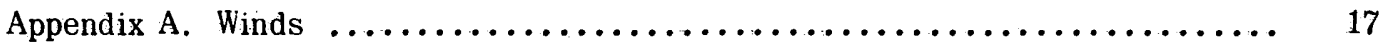

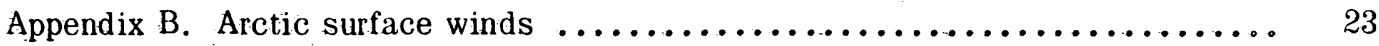

Appendix C. Excerpt from Cold Regions Science and Engineering, USA CRREL

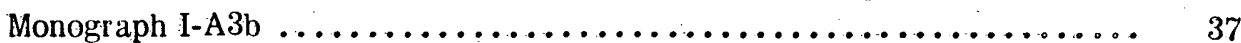

Appendix D. Excerpt from Proceedings of the Arctic Basin Symposium October 196249

Abstract ........................................... 55

\section{ILLUSTR ATIONS}

Figure

1. Location of coastal stations in the vicinity of the Arctic Ocean ........ 3

2. Boundary location of 6 zones within the Arctic Ocean .............. 5

3. Prevailing wind directions in the Arctic Ocean during the mid-winter months 10

4. Prevailing wind directions in the Arctic Ocean during the mid-summer months 11

5. Mean sea-level pressure for January, 1948-55 ................... 12

6. Mean sea-level pressure for July, $1948-55 \ldots \ldots \ldots \ldots \ldots \ldots \ldots \ldots \ldots \ldots . \ldots \ldots$

\section{TABLES}

Table

I. Prevailing surface wind directions, coastal stations in North America

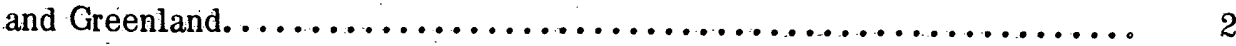

II. Prevailing surface wind directions, Arctic Ocean coastal stations in Europe and U.S.S.R. ........................................ 3

III. Prevailing wind directions in the interior Arctic Ocean .............. 6 


\title{
PREVAILING WIND DIRECTIONS IN THE ARCTIC OCEAN
}

by

\author{
Michael A. Bilello
}

\section{INTRODUCTION}

Except for a series of charts published by the U.S. Navy $(1958,1963)$, summarized information on prevailing wind directions in the Arctic Ocean is sparse. In this report wind data from 21 weather stations surrounding the Arctic Ocean and several stations within it are collected and examined. The Navy charts as well as other reports relative to the subject are included as appendices.

The survey produced monthly summaries of wind direction for the 21 stations around the Arctic Ocean. Eight of these stations, located in Alaska, Canada and Greenland, provided sufficient information to develop frequency tables showing seasonal variations (Table I). The compilations for Barrow and Barter Island, Alaska (Tables Ia and Ib), and Thule and Nord, Greenland (Tables Ig and Ih), were obtained from data given in the Uniform Summaries of Surface Weather Observations (U.S. Air Force 1942-1963). The results for Herschel Island, Mould Bay, Isachsen and Alert, Canada (Tables Ic-If), were obtained from the following Canadian publications: 1) Meteorological Observations (Dept. of Transport, Canada, 1941-1972), 2) Climatological Summaries (Dept. of Transport, Canada, 1957-1958) and 3) Meteorology of the Canadian Arctic (Dept. of Transport, Canada, 1944).

The mean monthly prevailing wind data given in Table II for the coastal stations in northern Europe and Siberian Russia were obtained from Climatology of the Arctic Regions, Part I (U.S. Air Force 1946).

\section{COASTAL STATIONS}

\section{Alaska}

Seasonal and annual frequencies for the two coastal stations in northern Alaska (Tables Ia and Ib) show a predominant east or northeast flow about $45 \%$ of the time. A seasonal breakdown showed that this situation exists throughout the year. Winds from the west and southwest are next in frequency at Barter Island and calm winds occur about $10 \%$ of the time. Barrow shows no particular secondary frequency in wind direction and recorded no wind only $2 \%$ of the time.

\section{Canada}

Moving eastward from Alaska along the northern coast of Canada we pass Herschel Island, Mould Bay, Isachsen and Alert in that order (Fig. 1). Herschel Island (Table Ic) records a nearly equal occurrence of west-northwest and east-southeast winds. The former occur slightly more frequently between December and May but the latter show no seasonal preference. The frequency of calm conditions is high: the yearly total is $17 \%$. 
Table I. Prevailing surface wind directions, coastal stations in North America and Greenland.

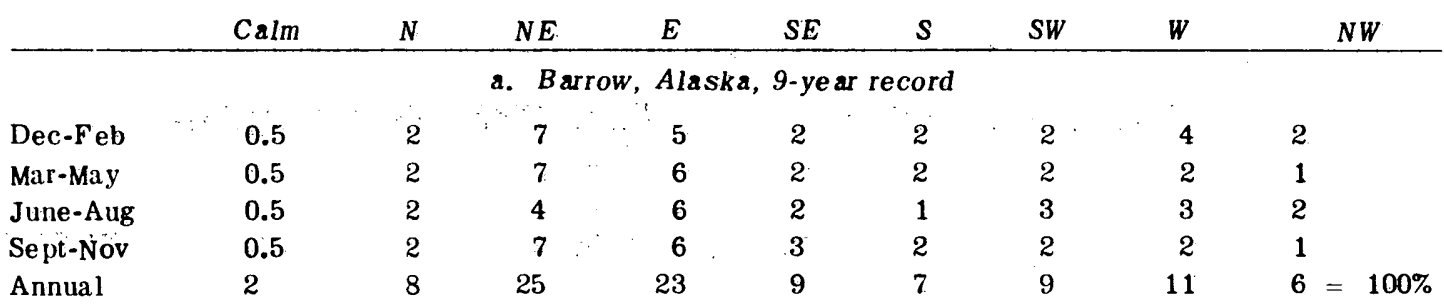

b. Barter Island, Alaska, 16-year record

\begin{tabular}{|c|c|c|c|c|c|c|c|c|c|}
\hline Dec-Feb & 2 & 0 & 3 & 6 & 1 & 1 & 5 & 6 & 0 \\
\hline Mar-May & 3 & 0 & 5 & 7. & 0 & 1 & 4 & 5 & 0 \\
\hline June-Aug & 3 & 2 & 7 & 6 & 0 & 0 & 2 & 4 & 2 \\
\hline Sept-Nov & 2 & 0 . & 5 & 6 & 1 & 2 & 3 & 5 & 1 \\
\hline Annual & .10 & 2 & 20 & 25 & 2 & 4 & 14 & 20 & $3=100 \%$ \\
\hline
\end{tabular}

c. Herschel Island, N.W.T.

$\begin{array}{llllllllllll}\text { Dec-Feb } & 5 & & 1 & 1 & 4 & 3 & 0.5 & 1 & 5 & 6 \\ \text { Mar-May } & 4 & & 1 & 1 & 5 & 3 & 0.5 & 1 & 4 & 6 \\ \text { June-Aug } & 4 & & 1 & 3 & 6 & 2 & 0.5 & 1 & 2 & 5 \\ \text { Sept-Nov } & 4 & & 1 & 1 & 4 & 4 & 0.5 & 1 & 2 & 6 \\ \text { Annual } & 17 & & 4 & 6 & 19 & 12 & 2 & 4 & 13 & 23=100 \%\end{array}$

d. Mould Bay, N.W.T., 6-year record

$\begin{array}{lrrrrrrrrrrr}\text { Dec-Feb } & 11 & 3 & 1 & 2 & 1 & 2 & 0.5 & 1 & 5 \\ \text { Mar-May } & 10 & 3 & 3 & 2 & 1.5 & 2 & 0.5 & 2 & 3 \\ \text { June-Aug } & 2 & 2 & 2 & : 1 & 1 & 3 & 2 & 3 & 5 \\ \text { Sept-Nov } & 6 & 4 & 2 & 2 & 1.5 & 2 & 2 & 2 & 4 \\ \text { Annual } & 29 & 12 & 8 & 7 & 5 & 9 & 5 & 8 & 17=100 \%\end{array}$

e. Isachsen, N.W.T., 6-year record

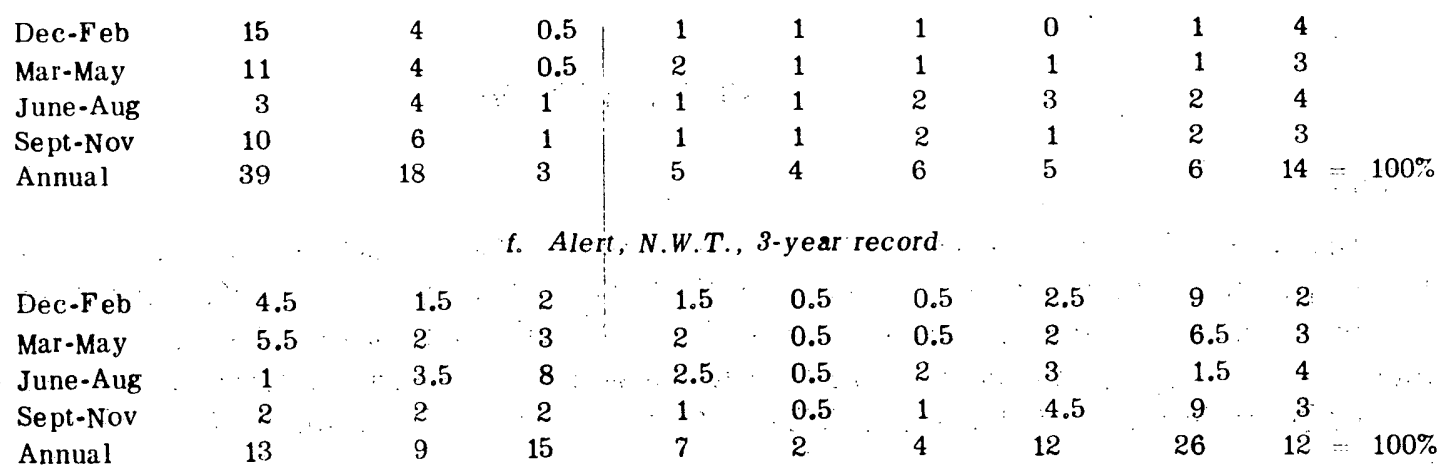

g. Thule, Greenland, 7-year record

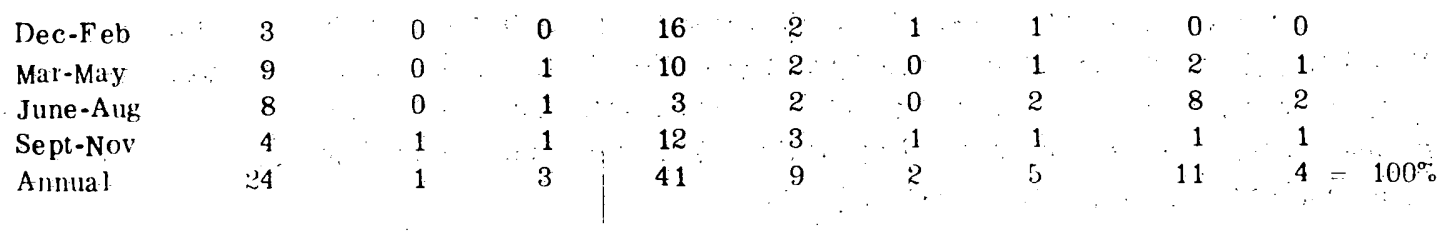

\begin{tabular}{|c|c|c|c|c|c|c|c|c|c|}
\hline Dec-F eb & 6 & 1 & 0.5 & 0.5 & 0.5 & 2 & 11 & 6 & 2 \\
\hline Mar-May & 7 & 1 & 0.5 & 3 & 1.5 & 2 & 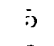 & 2 & 2 \\
\hline June-Aug & 9 & 1 & 0.5 & 3 & 0 & 4 & 3 & 1 & 2 \\
\hline Sept-Nov & 10 & $\because$ & 0.5 & 0.5 & 0 & 1 & 6 & 2 & 1 \\
\hline Annual & 32 & 5 & 2 & 7 & 2 & 9 & 25 & 11 & $\tau=100^{\circ}$ \\
\hline
\end{tabular}


Table II. Prevailing surface wind directions, Arctic Ocean coastal stations in Europe and U.S.S.R.

See Figure 1 for locations of stations.

\begin{tabular}{llllllllllllll}
\multicolumn{1}{c}{ Station } & Jan & Feb & Mar & Apr & May & June & July & Aug & Sept & Oct & Nov & Dec & $\begin{array}{c}\text { Average } \\
\text { annual }\end{array}$ \\
\hline Jan Mayen Island & NW & NW & NW & NW & E & E & E & E & E & NW & NE & NE & E \\
Tromso & SW & SW & SW & SW & SW & SW & NE & SW & SW & SW & SW & SW & SW \\
Vardo & SW & SW & SW & SW & NW & NW & NW & NW & NW & SW & SW & SW & SW \\
Kola (Murmansk) & SW & SW & SW & SW & SW & N & N & N & SW & SW & SW & SW & SW \\
Malye Karmakuly Island & E & SE & SE & E & E & NW & N & N & N & S & E & E & Var. \\
Archangel & SE & SE & SE & SE & NW & NW & NW & NW & SW & SW & SW & SE & SE \\
Yugorski Strait & S & S & S & S & NE & NE & NE & NE & S & S & S & S & S \\
Dickson-Island & S & S & S & S & NE & NE & NE & NE & S & S & S & S & S \\
Tiksi Bay & SW & SW & SW & SW & NE & NE & NE & E & W & SW & SW & SW & SW \\
Cape Schmidt & SE & SE & SE & SE & SE & SE & NW & SE & NW & NW & NW & SE & SE \\
Wrangel Island & NE & N & N & NE & NE & NE & N & E & NE & N & N & N & N \\
Uelen & N & N & N & N & N & N & S & S & S & N & N & N & N \\
St. Paul Island & NE & NE & NE & N & NE & NE & S & SW & NW & N & N & NE & NE \\
\hline
\end{tabular}

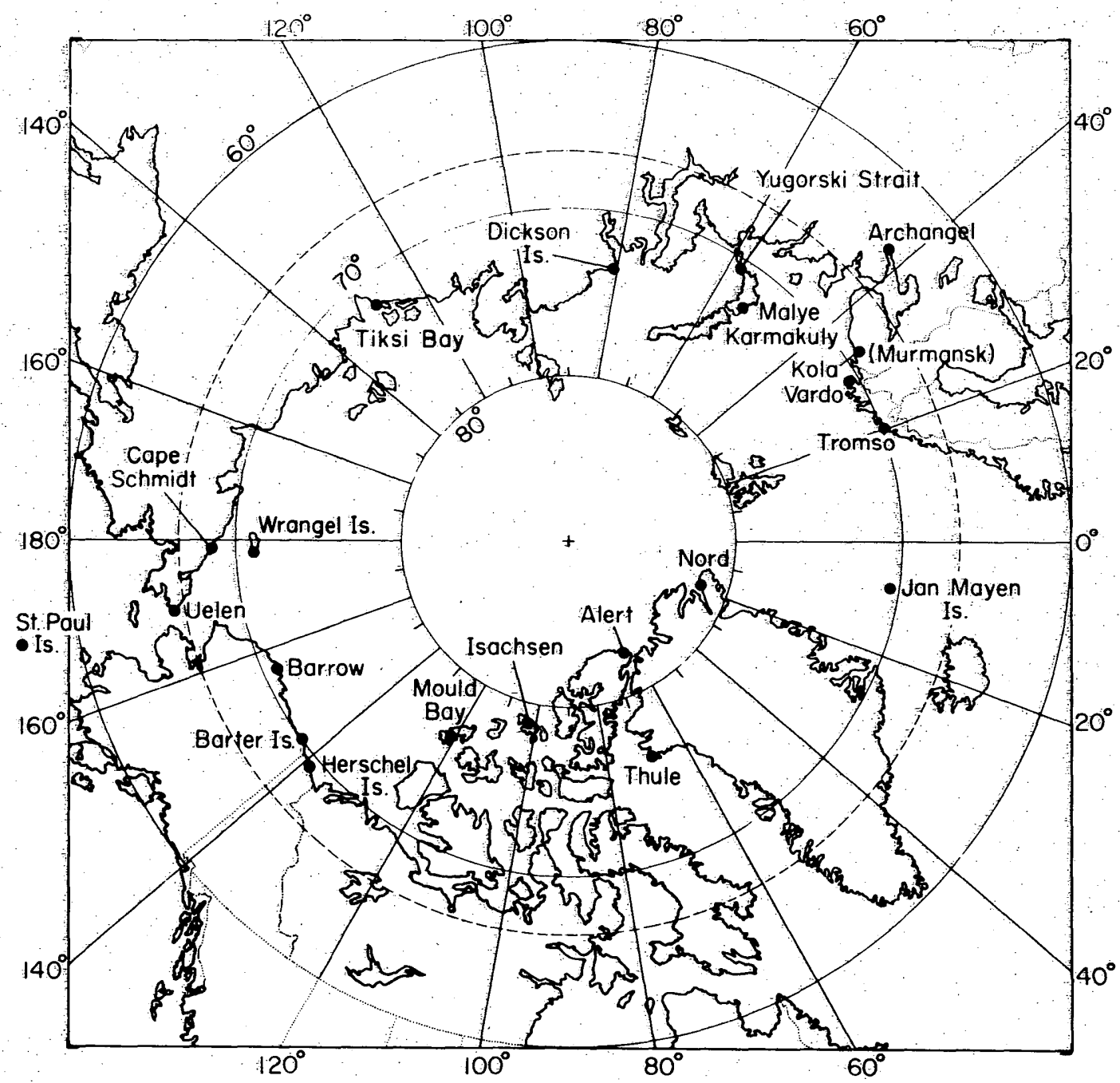

- Figure 1. Location of coastal stations in the vicinity of the Arctic Ocean. 
Mould Bay and Isachsen reported the highest annual frequency of calm periods, $29 \%$ and $39 \%$ (Tables Id and Ie). At both these locations a north-northwest flow of air predominates throughout the year (about $30 \%$ of the time). Winds from other directions occur at lesser frequency ( 3 to $9 \%$ ).

Alert, on the northeast corner of Ellesmere Island, experiences mostly westerly winds from September through May and northeast winds between June and August (Table If).

\section{Greenland}

Winds at Thule (Table Ig) are greatly influenced by the Greenland ice sheet. The strong katabatic flow of air descending from the higher elevations east of the station results in east or southeast winds during $50 \%$ of the year. The main exception occurs between June and August when the prevailing winds shift and come from the west. Calm periods are also common, occurring most frequently from March through Aug. At Nord, winds blow from the southwest $25 \%$ of the time, and from the south or west $20 \%$ of the time. The wind is calm about one third of the time and the only seasonal variation occurs during June through August when the direction becomes more variable.

\section{Europe and Russia}

Mean monthly surface wind directions for 13 stations on the northern coasts of Europe and the U.S.S.R. (Fig. 1) are given in Table II. Jan Mayen Island, directly east of Greenland, is actually in the Greenland Sea, but it has been included in the Eurasian group because wind direction data for Spitsbergen locations were not immediately available. Prevailing winds at Jan Mayen are northwest or northeast from October through April and east for the remainder of the year.

Tromso and Vardo in Norway, and Kola (Murmansk) in the U.S.S.R., are located on the northern tip of Europe. All report southwest winds between October and April. During the other months the winds remain mostly from the southwest at Tromso but shift to the north or northwest at the other two stations.

Five locations along the northern coast of Russia (Malye Karmakuly, Archangel, Yugorski Strait, Dickson Island and Tiksi Bay) experience mostly south, southeast or southwest winds between October and April. The only exception is Malye Karmakuly where an east wind is also common during these months. The seasonal wind shift at these five locations takes place around May when the direction becomes northeast, north or northwest until August or September.

Three of the four stations in the Chukchi and Bering Sea areas (Wrangel Island, Uelen and St. Paul Island) report similar mean monthly wind directions. Between October and June the prevailing wind is north or northeast, and between July and September it becomes variable. Cape Schmidt, although located between Wrangel Island and Uelen, reports wind directions opposite to those observed at the neighboring stations. "The wind blows from the southeast (rather than north or northeast) from December through June and mostly from the northwest between July and November. This anomaly may be due to local effects, such as mountains or a valley. The rugged terrain and the influence of the Bering Strait would be expected to affect the prevailing wind direction at Uelen also, but the records belie this assumption.

\section{THE INTERIOR ARCTIC OCEAN}

The analysis in this part of the study covers stations in the interior portion of the Arctic Ocean. Meteorological observations in this region are made on U.S. and Russian floating ice floe and ice island stations; no permanently located stations are involved. 


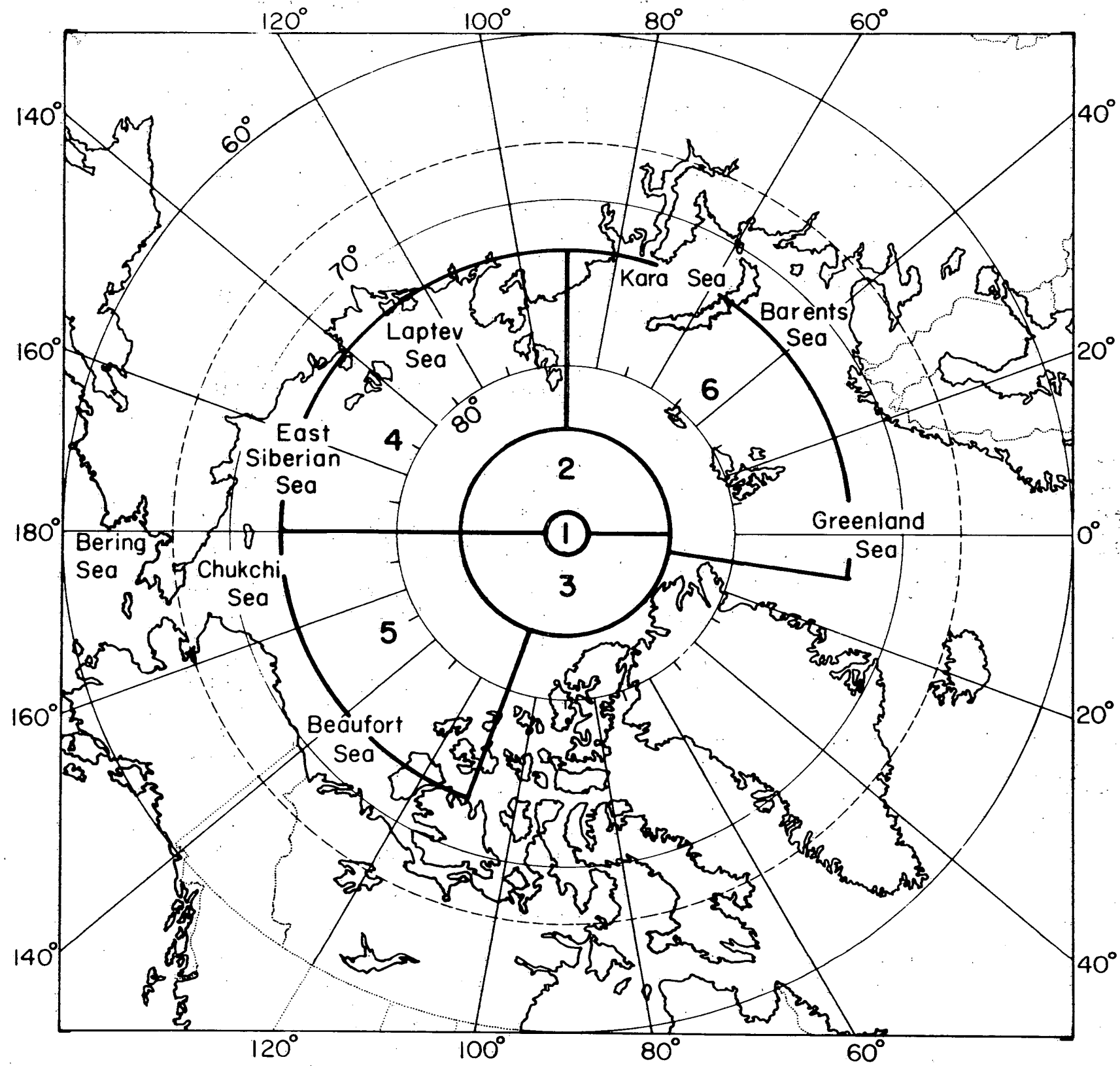

Figure 2. Boundary location of 6 zones within the Arctic Ocean.

A series of surface wind roses for the Arctic Ocean was published in Oceanographic Atlas of the Polar Seas (U.S. Navy 1958) using data collected from various drifting ice stations. These charts, as well as the text which accompanied them (Appendix A), will be used as the reference material for the following discussion.

For this analysis of surface wind directions during February, May, August and November, the Arctic Ocean was divided into six zones (Fig. 2):

Zone 1: the area in the immediate vicinity of the North Pole.

Zone 2: the eastern hemisphere, from $0^{\circ}$ to $180^{\circ} \mathrm{E}$, and $84^{\circ} \mathrm{N}$ to $89^{\circ} \mathrm{N}$.

Zone 3: the western hemisphere, from $0^{\circ}$ to $180^{\circ} \mathrm{W}$, and $84^{\circ} \mathrm{N}$ to $89^{\circ} \mathrm{N}$. 
Table III. Prevailing wind directions in the interior Arctic Ocean.

The boundaries of these six zones are shown in Figure 2.

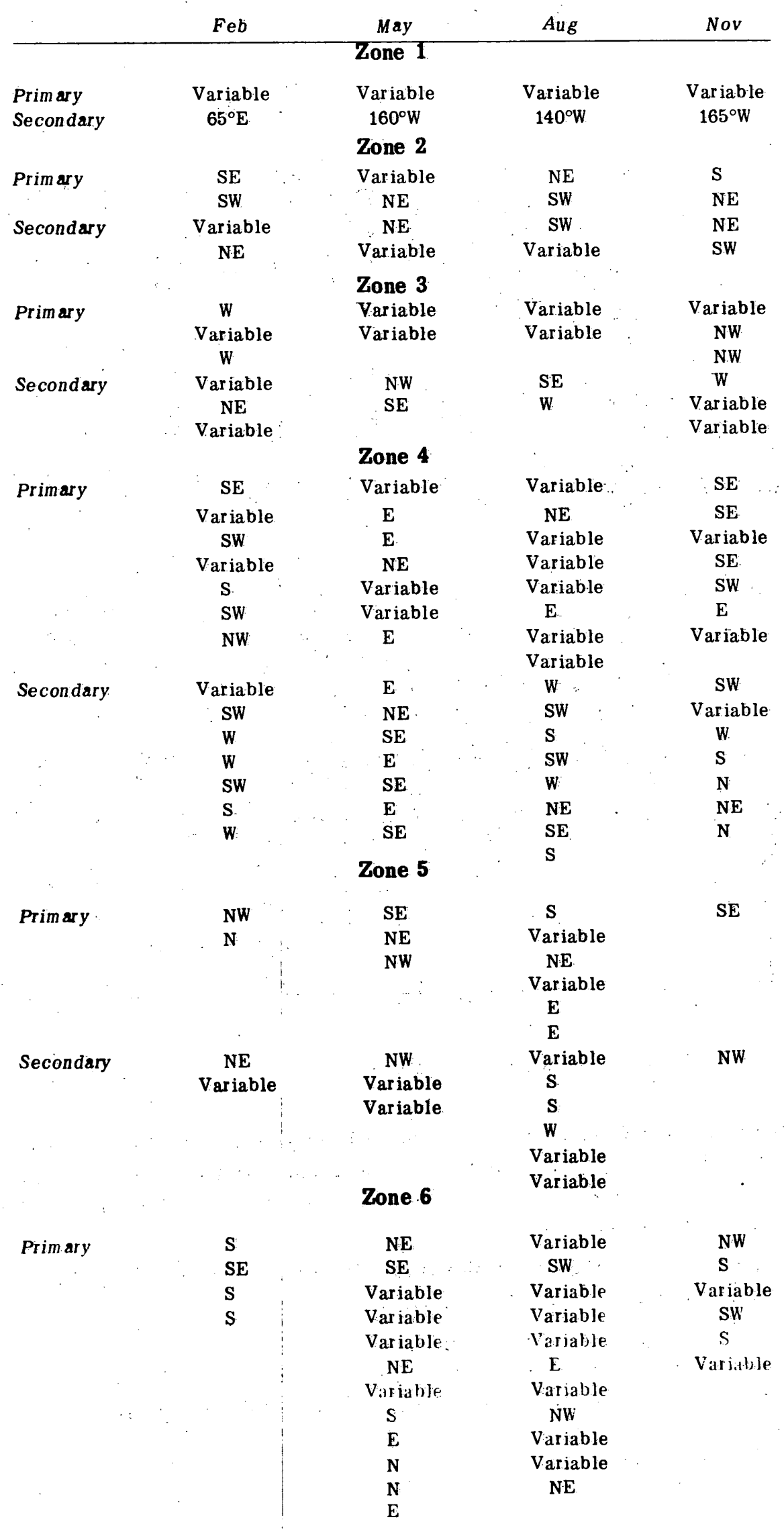




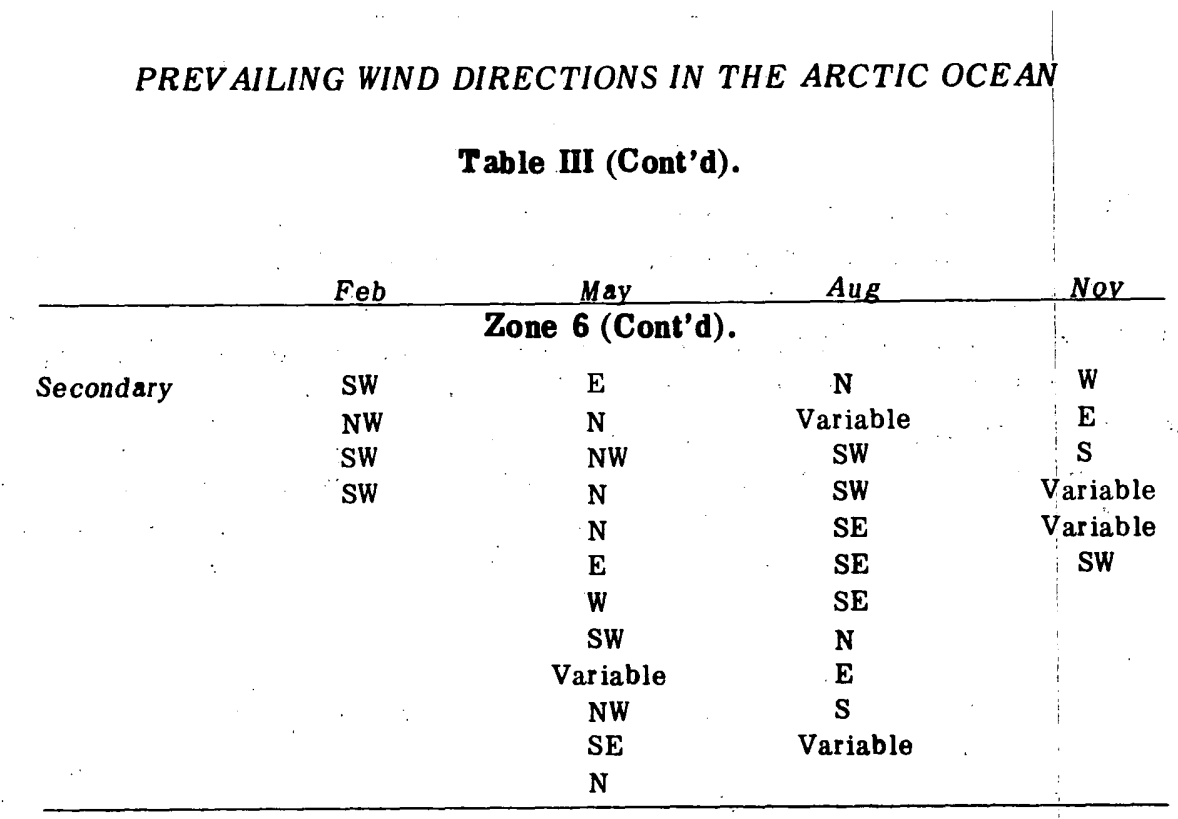

Zone 4: the area between $90^{\circ} \mathrm{E}$ and $180^{\circ} \mathrm{E}$, and $73^{\circ} \mathrm{N}$ and $84^{\circ} \mathrm{N}$.

Zone 5: the area between $110^{\circ} \mathrm{W}$ and $180^{\circ} \mathrm{W}$, and $73^{\circ} \mathrm{N}$ and $84^{\circ} \mathrm{N}$.

Zone 6: the area between $10^{\circ} \mathrm{W}$ and $90^{\circ} \mathrm{E}$, and $73^{\circ} \mathrm{N}$ and $84^{\circ} \mathrm{N}$.

These zones were selected on the basis of a logical separation of bodies of water within the Arctic Ocean and also for convenience. The primary and secondary prevailing wind directions observed at sites within these zones during February, May, August and November are given in Table III.

\section{Zone 1}

In the vicinity of the North Pole the winds are often light and variable in direction. Since all winds exactly at the North Pole would theoretically be from the south, directions are given in degrees of longitude. As shown in Table III, the winds near the North Pole show some preference to blow from between $140^{\circ} \mathrm{W}$ and $165^{\circ} \mathrm{W}$ during the period May through November and from about $65^{\circ} \mathrm{E}$ during the mid-winter months.

\section{Zone 2}

The two stations in Zone 2 show two prevailing wind directions. Table III shows that in 6 out of 16 summarized cases the wind is from a northeasterly direction, and in 4 cases it is southwesterly. Variable wind directions were recorded in 4 instances, and south or southeast winds twice. No particular seasonal preference for wind direction was noted, but it is significant that when the wind is not light and variable in direction it generally blows from either of two opposite directions, northeast or southwest.

\section{Zone 3}

Unfortunately observations from only a few sites were avallable for study in this zone. The records show that during most of the year the wind direction in this region is variable (Table III). There is some preference for west or northwest winds, but no particular seasonal distribution of any dominant wind direction was noted. Until data for more stations become available, conclusions on prevailing wind directions for this area can only be tentative. 


\section{Zone 4}

This portion of the Arctic Ocean includes the Laptev and East Siberian seas (Fig. 2). Wind roses for seven to eight locations were available in this zone throughout the year. Considerable variability exists, especially during August. There is some preference for winds to blow from the southeast to northeast between May and November, and from the southwest in February. The survey of wind directions of secondary frequency showed little consistency. Some trends are indicated though: during February winds are from the south, southwest or west, and during May they are from the southeast, east or northeast. The survey of secondary wind directions during August and November for this area shows no preference for any particular wind direction.

\section{Zone 5}

Zone 5 includes most of the western half of the Arctic Ocean and part of the Beaufort Sea. The number of stations available varied considerably throughout the year. Wind roses for six stations were given for August (Fig. A3), whereas data for only one to three sites were given for November, February and May (Fig. A1, A2 and A4).

The survey of primary and secondary frequencies of wind direction (Table III) provided only tentative results because of the lack of data. In 7 of the 12 cases (primary and secondary frequencies) surveyed for November, February and May the winds mostly blew from between the northwest and northeast quadrants. In 3 of the 6 cases of secondary frequency for these months the wind direction was variable and 2 of the 6 primary listings show that the wind for these months is from the southeast. During August the wind directions become variable, with perhaps a slight preference for south and east winds.

\section{Zone 6}

Zone 6 includes the European portion of the Arctic Ocean, the Greenland Sea, the Barents Sea and part of the Kara Sea (Fig. 2). A greater number of wind roses are available in Zone 6, because the bodies of water here are ice-free for a longer period and because there is more shipping activity in the area. However, the additional wind data still did not give a definite picture of prevailing wind directions.

The survey of wind direction of primary frequency (Table III) showed that the winds are variable throughout the year. A slight exception exists during February and November when 7 of the 10 compiled cases show that the winds blow from the south.

The analysis of wind roses with respect to secondary frequency offered some help in deter* mining dominant directions. For example, 6 of the 12 wind directions of secondary frequency in May are nor $\mathrm{th} ; 3$ of the 4 in February are southwest; 6 out of 11 in August are south; but in November no prevailing wind direction is evident.

When both the primary and secondary compilations are considered and the variable wind directions are omitted, the wind is from the south in 23 of the 48 possible cases and from the north in 16 cases throughout the year. Combining the 66 annual events used in the analysis (including the variable wind directions), the following general statement could be made. In Zone 6 the winds are from the south about $50 \%$ of the time and either from the north or variable the other $50 \%$. On a seasonal distribution the survey indicated a strong preference for northerly winds during May and a preference for southerly winds during August, November and February. 


\section{SUMMARY AND DISCUSSION}

Almost all stations along the Arctic Ocean coastline record a preferred wind direction during the long winter, which extends from about October to April or May. Along the north Alaskan coast this preferred direction is east or east-northeast and along the Canadian Archipelago Islands it is mostly north. On the northeast coast of Greenland and across all of the northern coasts of Europe and central U.S.S.R. the prevailing winter winds are clearly from the south. Except for Cape Schmidt the stations near the northwest coast of the U.S.S.R. exhibit a major reversal in winter wind direction, shifting from the south to the north or northeast.

During the shorter warm weather period which extends from about May to September the average wind speeds generally decrease and the directions become variable. At those stations where a dominant wind direction does develop it is usually about $180^{\circ}$ from the winter direction. Finally it should be noted that because these stations are located near a coastline they may be influenced by topography or local thermal conditions such as land and sea breezes. Stations which exhibit such anomalies are Thule, Greenland; Cape Schmidt, U.S.S.R.; and Herschel Island, Canada. However, since similar wind directions were obtained for two or more stations within limited areas the results appear to be representative.

The few stations in the circle north of $84^{\circ} \mathrm{N}$ report mostly variable wind directions. When a preferred wind is observed it is usually southwest or northeast in the eastern part of the hemisphere and west or northwest in the western half. In the vicinity of the North Pole: some preference for winds from the direction of northwestern Russia is shown during February and from the direction of Alaska during May, August and November.

In the Laptev and East Siberian Seas consistent patterns appeared during only two periods; southwest winds were noted in February and southeast through northeast winds in May. Information from the western half of the Arctic Ocean including the Beaufort Sea was sparse. Northerly winds occur quite often in this area between November and May and in mid-summer winds become variable.

In the European region of the Arctic Ocean, including the Greenland, Barents and Kara Seas, prevailing wind directions are difficult to analyze. The Greenland ice sheet, the continents and numerous large islands influence the wind direction so that there is no persistent pattern of prevailing winds within the region. Some preference, though, was noted for northerly winds during May, and for southerly winds in August, November and February.

The prevailing wind directions obtained in Parts I and II were combined and the results are shown in Figures 3 and 4. The prevailing winter wind patterns (Fig. 3) may be summarized as follows:

1) near anticlockwise flow within the circle north of $75^{\circ} \mathrm{N}$;

2) north winds in the Chukchi Sea, Bering Strait and Bering Sea;

3) northeast winds along the north coast of Alaska and northwest winds along the Canadian Archipelago Islands;

4) continued west or northwest winds off the northeast coast of Greenland;

5) a pronounced shift of prevailing winds to southwest along the northwestern tip of Europe;

6) southeast or southwest winds along the northern coast of the U.S.S.R.

Although prevailing wind directions during the summer months become more variable the composite picture (Fig. 4) shows the following patterns:

1) in zones 1-6 prevailing winds in summer flow clockwise around the Pole;

2) stations north of the Bering Strait record northerly winds, while those south of the strait report southerly winds; 


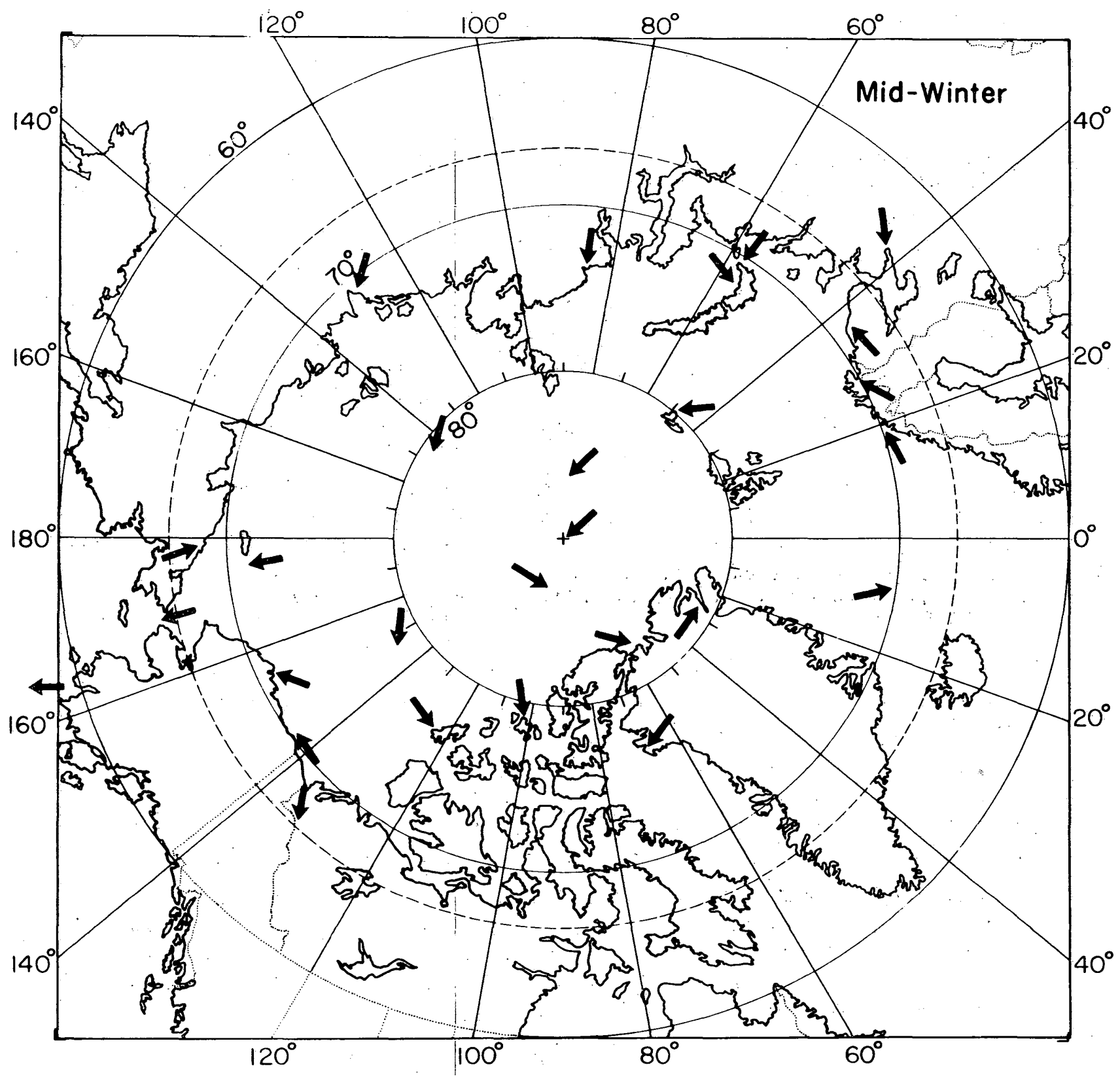

Figure 3. Prevailing wind directions in the Arctic Basin during the mid-winter months.

3) stations along the north coast of Alaska experience easterly winds, but the Canadian Archipelago has southwest winds;

4) westerly winds at Thule and Nord, Greenland, appear to be largely controlled by local factors;

5) along the northwest tip of Europe the summer winds shift to the northwest and northeast;

6) along the north coast of the U.S.S.R., the prevailing winds shift almost $180^{\circ}$ from winter to summer and blow from a northeast direction in summer.

Prevailing surface wind directions are closely associated with the isobaric pressure distribution observed at sea level. Hare and Orvig (1958) reproduced some maps originally developed by J. Namias which show the mean sea level pressure for the north Polar region. The maps for January 


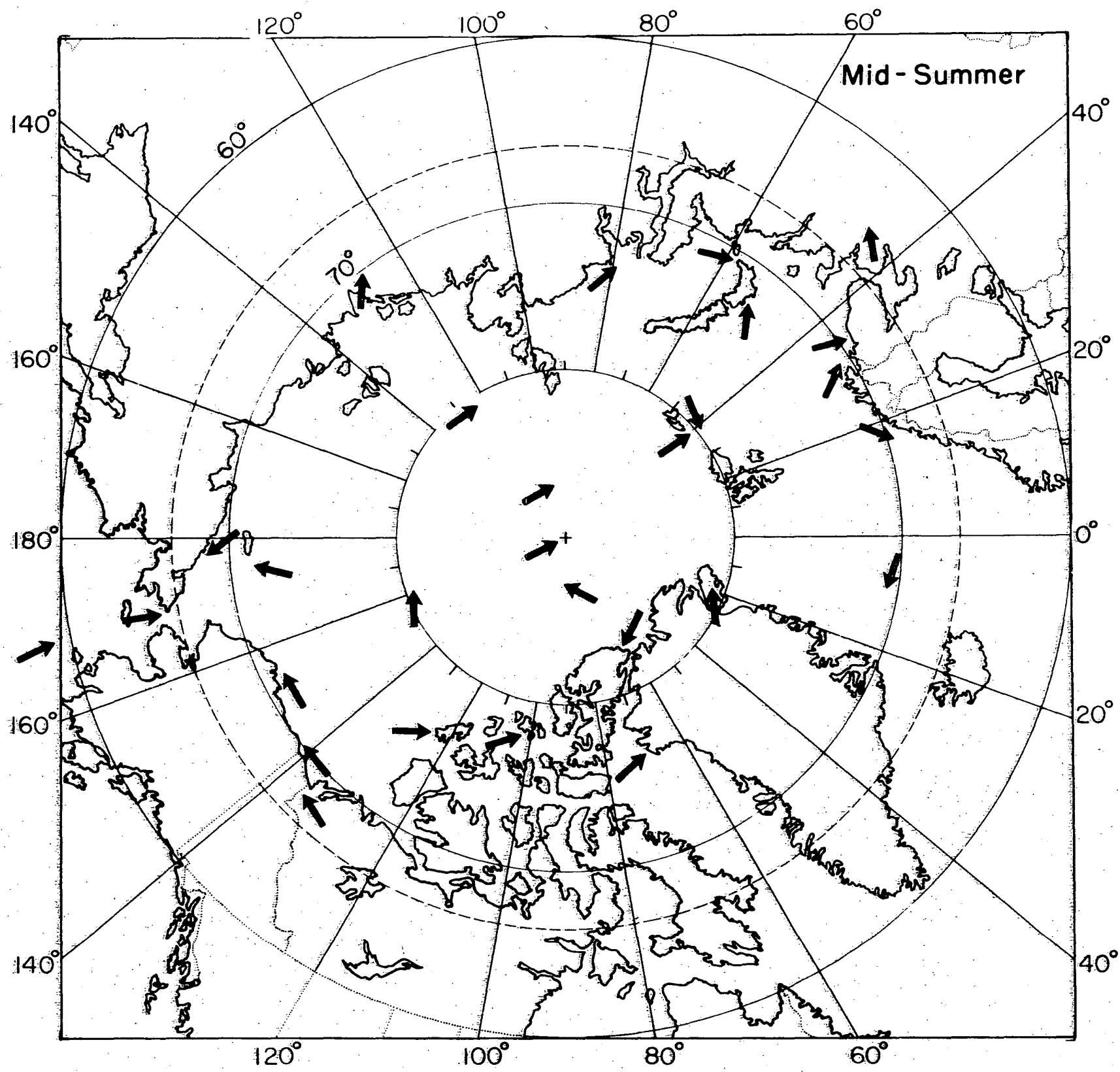

Figure 4. Prevailing wind directions in the Arctic Basin during the mid-summer months.

and July, covering the period between 1948 and 1955 , are shown in Figures 5 and 6 . In the following discussion the wind directions implied from the pressure distribution presented in Figure 5 will be compared with the observed flow shown in Figure 3.

The three most dominant features on the January map (Fig. 5) are: 1) the Siberian High which extends across most of the land mass of northern Asia, 2) the Aleutian Low which extends over all of the north Pacific Ocean, and 3) the Icelandic Low which is centered between southern Greenland and Iceland with a trough that extends into the Barents Sea. Surface wind directions implied by this pattern are also shown in Figure 5. When these implied directions are compared with those given in Figure 3 one finds considerable agreement and some notable differences. Best agreements are found 


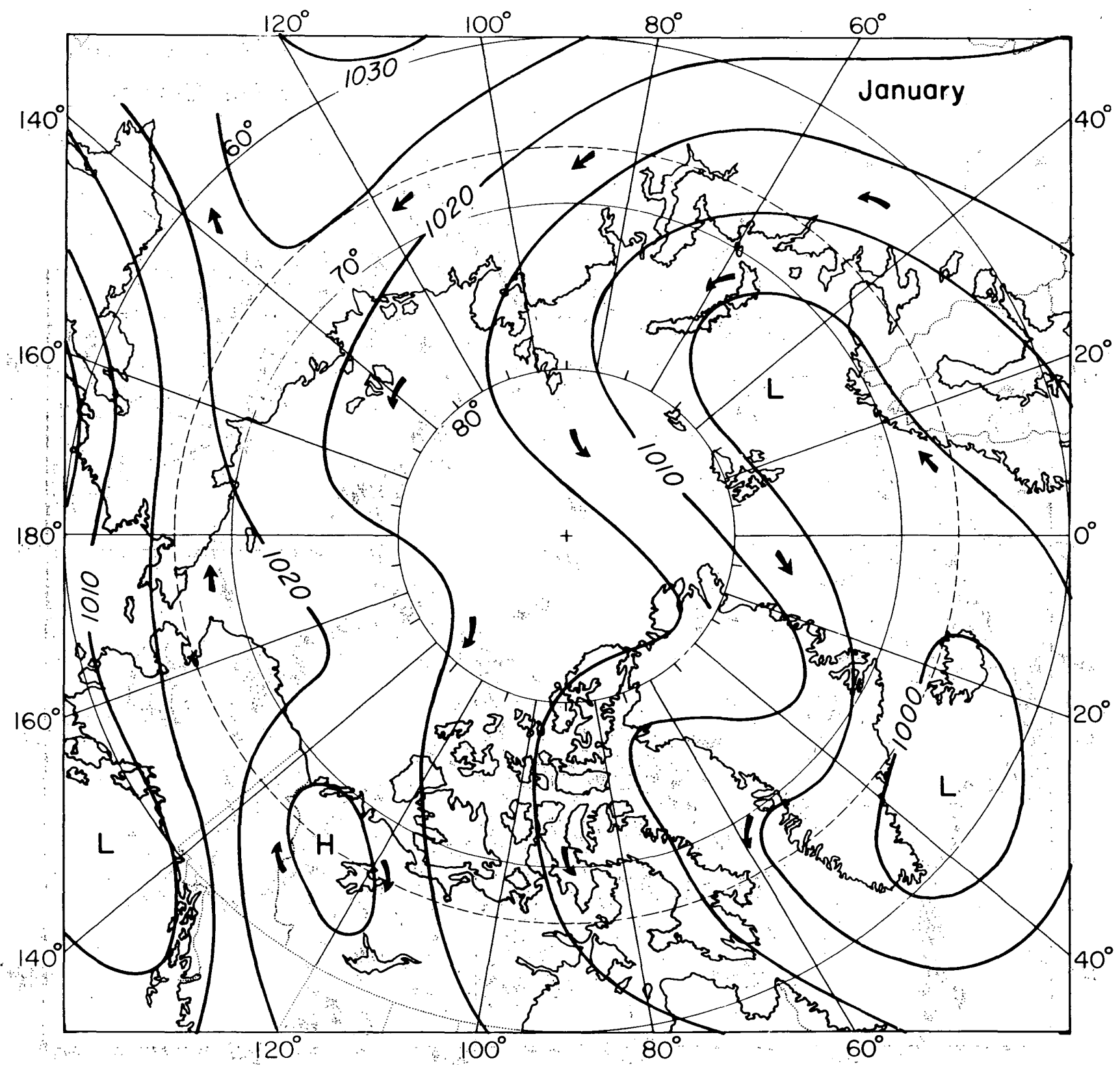

Figure 5. Mean sea-level pressure for January, 1948-55. (From Hare and Orvig 1958, after Namias.)

along: 1) the northwest coast of Norway, where southwesterly winds are indicated in both figures, 2) the north central coast of Russia, where winds from the south and southeast are most prevalent, and 3) the north coasts of the Canadian Archipelago Islands, where northerly winds are noted in both figures.

Areas that show some differences in prevailing winter wind directions are: "1) the north coast of Alaska where the small high pressure center in Figure 5 indicates a wind flow other than the northeast direction observed at Barrow and Barter Island, Alaska; 2) three locations in the Chukchi Sea, Bering Strait and Bering Sea record north winds in winter, whereas the isobaric 


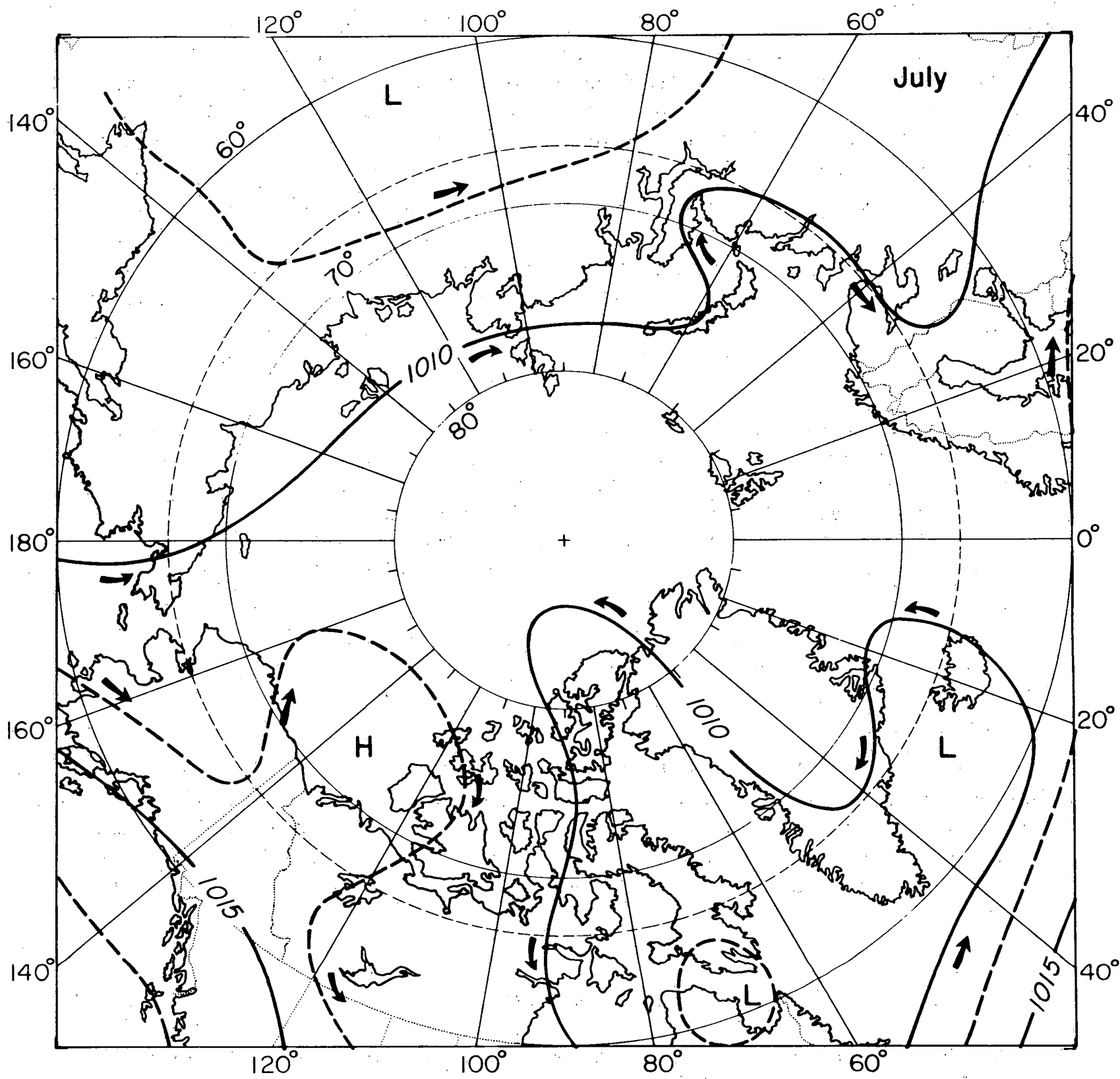

Figure 6. Mean sea-level pressure for July, 1948-55. (From Hare and Orvig 1958, after Namias.)

conditions indicate an easterly flow in the area (Fig. 5); an exception for this area is noted at Cape Schmidt, where winds from the southeast are reported. Although no definite comparisons can be made of wind direction within the circle north of $80^{\circ} \mathrm{N}$, the flow of air in Figures 3 and 5 appears to be from the eastern half of the Northern Hemisphere to the western half. However, the easterly direction of winds north of Greenland and Ellesmere Island (Fig. 5) produces an apparent slight clockwise flow in that area.

The surface barometric gradients in the Arctic region are not as steep in summer (Fig. 6) as they are in winter (Fig. 5). This condition would account for the variability in wind directions (noted earlier) during this season. The pressure centers in July (Fig. 6) also differ from those in 
January (Fig. 5). The high over the land mass of northern Asia in mid-winter is a weak low in midsummer, and the deep Aleutian and Icelandic lows of January are markedly weakened or replaced by a ridge of high pressure in July. The direction of the surface wind flow observed in summer (Fig. 4) was compared with the direction implied from the mean pressure shown in Figure 6. A situation similar to that noted during the winter was found in summer. Some areas showed good agreement, others did not.

Westerly winds appear on both figures along the north coast from central Siberia to the Kara Sea. The observed wind directions in summer along the Canadian Archipelago Islands are westerly (Fig. 4) and in Figure 6 the isobars indicate a northwesterly flow. In the Bering Sea and Bering Strait region both figures show the winds blowing from the south. However, just to the north of the area, at Wrangel Island and along the north coast of Alaska, the directions shown on each figure are not in agreement; the observed directions in Figure 4 are northeast and the flow implied by the isobars in Figure 6 is southeast.

Since the pressure gradient in the central Arctic Ocean and across the Barents and Greenland Sea is shown to be so weak (Fig. 6), estimates of probable prevailing summer wind directions for this area can not be made. Persistency of the observed wind directions at adjacent stations in Figure 4 indicates a degree of confidence for northerly winds along the northwest tip of Europe, and a clockwise flow of air in the Arctic Ocean interior. Wind directions at the few coastal stations in Greenland show no particular pattern and as noted earlier are probably influenced by local topography.

The pattern of the surface water currents in the Arctic Ocean interior is also described in the Oceanographic Atlas (U.S. Navy 1958). The circulation in the eastern half of the ocean was found to be slow and westerly. On the western side, north of Alaska, a large gyral moving clockwise is indicated. The directions of these mean currents in the ocean's interior are similar to the prevailing winds described during the summer period in this study.

The marginal seas of Russia exhibit an easterly flow along the coast of the continent and westerly along the northern limits. It is noted that the circulation in the Laptev Sea is particularly significant because the counterclockwise gyral centered there at times increases in size to include a large part of the Arctic Ocean. The Norwegian Current is derived from Atlantic water and flows northward along the coast. The directions of these mean currents along these coasts are similar to the prevailing winds observed during the winter.

\section{SUPPLEMENTAL DATA}

A series of monthly bar graphs showing the wind speed and direction for stations north of $60^{\circ} \mathrm{N}$ were published by the U.S. Navy (1963). These charts have been included in this report for reference purposes (Appendix B). No attempt was made to analyze this information. The charts provide additional stations and/or data, and also give information for all the months of the year.

Two other articles which provide some information on wind directions in the Arctic are presented in Appendices C and D. The section on Surface Winds in USA CRREL Monograph I-A3b, Climatology of the Cold Regions, Northern Hemisphere II by C. Wilson, 1969 (Appendix C) provides information on average and maximum wind speeds and prevailing directions and on wind loads and blowing snow for stations in the Arctic. However, the study provides very little data on wind direction for stations in Eurasia or the Arctic Ocean. In the section on Surface Winds in the Proceedings of the Arctic Basin Symposium, October 1962, Arctic Institute of North America, 1963 (Appendix D) the coriolis force and geostrophic winds are discussed. No values on prevailing wind directions in the areat are given in the report. 


\section{LITERATURE CITED}

Arctic Institute of North America (1963) Proceedings of the Arctic Basin Symposium, October, 1962, Hershey, Pa.

Department of Transport, Canada (1941-1972) Meteorological observations - monthly. Meteorological Branch, Toronto, Canada.

Department of Transport, Canada (1944) Meteorology of the Canadian Arctic. Air Services Branch, Meteorological Branch, Toronto, Canada.

Department of Transport, Canada (1957-1958) Climatological summaries for Isachsen and Mould Bay. Meteorological Branch, Toronto, Canada.

Hare, F.K. and S. Orvig (1958) The arctic circulation. Arctic Meteorology Research Group, McGill University, Publication in Meteorology No. 12.

U.S. Air Force (1942-1963) Uniform summary of surface weather observations for selected stations in Alaska, Canada and Greenland. Air Weather Service, Data Processing Division, Asheville, N.C.

U.S. Air Force (1946) Climatology of the arctic regions, Part I. Headquarters, Air Weather Service, Washington, D.C.

U.S. Navy (1958) Oceanographic atlas of the polar seas. Hydrographic Office Publication No. 705, Part 2, Arctic, Wa shington, D.C.

U.S. Navy (1963) Marine climatic atlas of the world, Volume VI, Arctic Ocean. NAVWEPS 50-1C-533, Chief of Naval Operations, Wa shington, D.C.

Wilson, C. (1969) Climatology of the cold regions, Northem Hemisphere II. U.S. Army Cold Regions Research and Engineering Laboratory (USA CRREL) Monograph I-A3b. 


\section{APPENDIX A. WINDS}

From Oceanographic Atlas of the Polar Seas, U.S. Navy Hydrographic Office Publication No. 705, P.art 2, 1958, Arctic, Washington, D.C.

Because waves are principally dependent upon wind force and direction, charts of surface wind roses for the months representative of the four seasons are presented in Figures A1, A2, A3, A4: In many places, contiguous areas have been combined if the wind conditions were similar.

The following types of roses, in order of reliability based on available data, were drawn:

1. Regular roses, indicated by thin circles, were compiled from U.S. Weather Bureau punch card decks (108). Except for one rose in the quadrangle bounded by $75^{\circ}-80^{\circ} \mathrm{N}$ and $150^{\circ}-160^{\circ} \mathrm{E}$ for November, all regular roses are based on a minimum of 100 observations; hence, the regular rose, as typified by that centered at $67.5^{\circ} \mathrm{N}, 5.0^{\circ} \mathrm{W}$ for February, constitutes the most reliable index of winds over open water.

2. Land station, ice island, and weather ship wind roses are depicted by stippled circles. Land roses were compiled from various land station punch card decks (108). As these winds always were observed on land where orographic factors or local heating may affect their direction or change their speed appreciably, the roses are not necessarily representative of wind conditions at sea. An example is that presented for Barrow, Alaska, for February. Seven ice island wind roses (Source 95) are presented for "North Pole 4" and "T-3" plotted at their mean monthly positions. Roses for the two Atlantic weather ships "Alfa" and "Metro" are presented at $62^{\circ} \mathrm{N}$, $33^{\circ} \mathrm{W}$ and $66^{\circ} \mathrm{N}, 2^{\circ} \mathrm{E}$, respectively (Source 108). Because of their great distance from land, ice island and weather ship roses are as representative of oceanic winds as "regular roses."

3. Theoretical roses, shown by double circles, were based on 40 to 99 observations for each ocean quadrangle. These roses, like regular roses, are located in areas bounded by thick lines to emphasize the exclusively oceanic origin of the data as derived from marine punch card decks. They were constructed by normalizing available wind observations according to a special application of Brooks and Carruthers' statistical method (12). A theoretical rose, as exemplified by that located to the northeast of Iceland in February, affords a satisfactory approximation to the actual conditions over the open sea in the absence of more complete data.

4. Scaled roses, denoted by thick circles, were derived from a 5-year series of Northern Hemisphere daily surface weather charts (107). In the computations the wind was assumed to flow toward low pressure at an angle of $20^{\circ}$ to $30^{\circ}$ to the isobars and with a speed proportional to the spacing between isobars. The scaled rose, such as appears at the North Pole in February, is an approximation made necessary by the absence of data over the icelocked regions and unfrequented waters of the Arctic.

The winds, as described by the roses, were distributed among 8 directions and 5 speed groups and plotted to the nearest whole percent. To determine the percentage of winds from a certain direction, the total length of the arm facing that direction should be measured and compared with the inset "percentage frequency scale" that accompanies each chart. Thus, 40 percent of the winds observed at Thule, Greenland are southeasterly during February; 28 percent are easterly at Barrow, Alaska, during the same period. 


\section{Selected references}

12. Brooks, C.E.P. and Carruthers, N. Handbook of statistical me thods in meteorology. M.O. 538. London: H.M. Stationery Offiee. 412 p. 1953.

95. U.S. Air Weather Service. Uniform summary of surface weather observations, Ice Island T-3. Pt. A, Derived from hourly observations. Pt. B, Derived from daily observations. Asheville: National Weather Records Center. 126 p. 1955? Unpublished.

107. U.S. Weather Bureau. Daily series synoptic weather maps; Northern Hemisphere sea level and 500 millibar charts with synoptic data tabulations. Pt. II, For months of February, May, August, November, 1951-1955.

108. National Weather Records Center. Climatological data for Marsden Squares 217-288, 901936. Tabulated by the U.S. Weather Bureau from the following decks: 100 (Russian Teletype Synoptic Observations, 1946-1949); 101 (Northem Hemisphere Observations, 1899-1928); 107 (Hamburg, Deutsche Seewarte Wetterbericht, August 1929-July 1939); 110 (WBAN, U.S. Navy Marine 1945-1951); 115 (U.S. Merchant Marine, 1938-1948); 116 (U.S. Merchant Marine, 1949-1953); 120 (Russian Teletype Synoptic Observations, 1950-1953); 142 (WBAN 1, Hourly Surface Observations, 1945-1948); 144 (WBAN 1, Hourly Surface Observations, 1948-1955); 167 (Nord, Greenland, Synoptic Observations, 1949-1954); 192 (Hamburg, Deutsche Seewarte, 1850-1943); 193 (Nederlands, Meteorologisch Instituut, 1854-1938); 194 (Great Britain Meteorological Office); 195 (U.S. Navy Ships' Logs, 1942-1945); 196 (Hamburg, Deutsche Seewarte Marine, 1949-1956); 197 (Denmark, Meteorologi ske Institut, 1912-1914); 281 (U.S. Navy MAR Synoptic, 1920-1945); and 296 (Canadian Synoptic and Summary of the Day, 1934-1953). Al so special British Observations from Harrow (1951-1953). Unpublished. 
APPENDIX C. EXCERPT FROM COLD REGIONS SCIENCE AND ENGINEERING, USA CRREL MONOGRAPH I-A3b

CLIMATOLOGY OF THE COLD REGIONS

NORTHERN HEMISPHERE II

by

C. Wilson

August 1969 


\section{SURFACE WINDS}

Few useful generalizations can be made concerning the distribution of surface winds in the cold regions. Although their distribution is related to the regional pressure gradients associated with cyclonic and anticyclonic systems, they are essentially local phenomena. In the high Arctic, the stability of the surface inversion layer and the influence of regional and local topography are frequently the factors that finally determine windspeed and direction. This is especially true in the case of maximum windspeeds and gustiness. At subarctic latitudes, the roughness of the surface is also a matter of the height and density of the vegetation cover* and the pattern of forest clearing.

The distribution of extreme windspeeds and peak gusts is poorly known in high latitudes. This is partly due to the sparse station network and instrument difficulties, but also to the tendency to occupy and operate from the more sheltered sites.

\section{Average Windspeeds and Prevailing Direction}

\section{Seasonal distribution}

In general, average windspeeds are greatest at exposed coastal stations wherever cyclonic activity is frequent and intense, and where the surface inversion is least intense and persistent. Table XLI indicates that coastal stations on the Arctic Ocean average 15 to $20 \mathrm{mph}(7$ to $9 \mathrm{~m} / \mathrm{sec})$ for exposed sites and about 10 to $15 \mathrm{mph}(4.5$ to $7 \mathrm{~m} / \mathrm{sec})$ where less exposed. Jan Mayen, Vardo and Ostrov Diksona show a well marked maximum during the winter months of maximum storminess, and a summer minimum when pressure gradients are less marked. Along the arctic coast of northeast Siberia, Alaska and Canada, the maximum mean windspeeds occur in summer/autumn when cyclones are frequent and the inversion weakest. The influence of exposure can be seen in the mean values for sheltered coastal stations such as Angmagssalik and Anchorage, with annual mean values of 4 and $5.5 \mathrm{mph}(2$ and $2.5 \mathrm{~m} / \mathrm{sec}$ ) respectively, in spite of their regional situation with respect to storm activity.

The lowest average windspeeds occur in the continental interiors under predominantly anticyclonic conditions, where pressure gradients tend to be weak winter and summer and where in winter the surface inversion reaches its maximum development. The stability of the inversion layer inhibits atmospheric mixing, so that the transport of kinetic energy from above is least under inversion conditions; the surface wind is therefore considerably less than the pressure gradient wind. Fairbanks, McGrath, Yakutsk and Verkhoyansk show annual mean windspeeds of 5, 4, 4 and 3 mph $(2.2,1.8,1.8$ and $1.3 \mathrm{~m} / \mathrm{sec})$ respectively. Winter is a period of calms and light winds, with maximum mean windspeeds in the summer months of about 6 or $7 \mathrm{mph}(3 \mathrm{~m} / \mathrm{sec})$ when the inversion is absent. The effects of continentality can become apparent within a very few miles of the coast where the relief creates frost hollows. Lake Hazen (Ellesmere l.) observations were compared with those at Alert and Eureka for the period of the IGY by Jackson. ${ }^{66}$ Hazen lies in a valley which is elongated northeast-southwest, about 100 miles from the other two coastal stations; mountains rise to over $3000 \mathrm{ft}$ on the northwest and southeast. Mean monthly windspeeds for the first half of 1958 were as follows:

\begin{tabular}{|c|c|c|c|c|c|c|c|c|}
\hline & Jan & $F$ eb & Mar & Apr & May & June & July & \\
\hline Lake Hazen & $\begin{array}{l}2.88 \\
1.25\end{array}$ & $\begin{array}{l}1.20 \\
0.53\end{array}$ & $\begin{array}{l}0.85 \\
0.38\end{array}$ & $\begin{array}{l}1.55 \\
0.70\end{array}$ & $\begin{array}{l}1.87 \\
0.83\end{array}$ & $\begin{array}{l}2.91 \\
1.30\end{array}$ & $\begin{array}{l}3.67 \\
1.63\end{array}$ & $\begin{array}{l}(\mathrm{mph}) \\
(\mathrm{m} / \mathrm{sec})\end{array}$ \\
\hline Alert & $\begin{array}{r}10.6 \\
4.7\end{array}$ & $\begin{array}{l}3.5 \\
1.6\end{array}$ & $\begin{array}{l}5.7 \\
2.5\end{array}$ & $\begin{array}{l}5.9 \\
2.6\end{array}$ & $\begin{array}{l}5.0 \\
2.2\end{array}$ & $\begin{array}{l}4.2 \\
1.9\end{array}$ & $\begin{array}{l}7.8 \\
3.5\end{array}$ & $\begin{array}{l}(\mathrm{mph}) \\
(\mathrm{m} / \mathrm{sec})\end{array}$ \\
\hline Eureka & $\begin{array}{r}11.4 \\
5.1\end{array}$ & $\begin{array}{l}5.7 \\
2.5\end{array}$ & $M$ & $\begin{array}{l}6.9 \\
3.1\end{array}$ & $\begin{array}{l}7.6 \\
3.4\end{array}$ & $\begin{array}{r}11.0 \\
4.9\end{array}$ & $\begin{array}{r}11.1 \\
4.9\end{array}$ & $\begin{array}{l}(\mathrm{mph}) \\
(\mathrm{m} / \mathrm{sec})\end{array}$ \\
\hline
\end{tabular}

* Estimated regional values of the aerodynamic roughness parameter, $z_{0}$, are given, by season, in ref. 77 , 78 and 162. 
Table XLI. Mean windspeed (mph) and direction, Northern Hemisphere.

\begin{tabular}{llllllllllllll}
$J$ & $F$ & $M$ & $A$ & $M$ & $J$ & $J$ & $A$ & $S$ & $O$ & $N$ & $D$ & $Y e a r$ \\
\hline
\end{tabular}

Canada $(1951-60)^{11} 160$

\section{Aklavik}

mean speed

prevailing direction

Alert

Mean speed

prevailing direction

Baker Lake

mean speed

prevailing direction

Cambridge Bay

mean speed.

prevailing direction

Chesterfield

mean speed

prevailing direction

clyde*

mean speed

prevailing direction

Coppermine

mean speed

prevailing direction

Coral Harbour

mean speed

prevailing direction

Eureka

mean speed

prevailing direction

Frobisher Bay

mean speed

prevailing direction

\section{Holman}

mean speed

prevailing direction

\section{Isachsen}

mean speed

prevailing direction

Mould Bay

mean speed

prevailing direction

Nottingham I. .

mean speed

prevailing direction

\begin{tabular}{|c|c|c|c|c|c|c|c|c|c|c|c|c|}
\hline 6.0 & 5.6 & 6.5 & 7.4 & 7.3 & 7.8 & 7.0 & 7.0 & 7.0 & 6.2 & 5.2 & 5.7 & 6.6 \\
\hline $\mathrm{S}$ & $\mathbf{S}$ & NW & $\mathrm{N}$ & $\mathbf{N}$ & $\mathrm{N}$ & NW & NW & NW & NW & NW & NW. & \\
\hline & . & & & & & & & & & & : & \\
\hline 5.0 & 5.1 & 4.6 & 4.9 & 5.1 & 6.5 & 7.6 & 6.0 & 6.4 & 6.9 & 5.8 & 4.6 & 5.7 \\
\hline$w$ & W & $\mathbf{W}$ & $\ddot{\mathbf{w}}$ & WNW & $\mathrm{NE}$ & NE & $\mathrm{NE}$ & W & W & $w$ & W. & \\
\hline 4.6 & 14.1 & 13.5 & 14.1 & 14.2 & 12.0 & 11.3 & 12.7 & 13.6 & 15.0 & 14.6 & 14.8 & 13.7 \\
\hline NW & NW & $\mathbf{N}$ & $\mathbf{N}$ & $\mathrm{N}$ & $\mathbf{N}$ & $\mathbf{N}$ & $\mathrm{N}$ & NW & $\mathbf{N}$ & $\mathrm{N}$ & $\mathrm{N}$ & \\
\hline & & & & & & & & & & & . & \\
\hline 2.3 & 10.7 & 10.6 & 12.3 & 12.7 & 12.9 & 12.9 & 12.8 & 13.4 & 14.0 & 12.0 & 10.8 & 12.3 \\
\hline$W$ & $\mathbf{W}$ & W & $\mathrm{N}, \mathrm{NW}$ & NW & $\mathbf{N}$ & $\mathrm{N}$ & $\mathbf{E}$ & $\mathrm{E}, \mathrm{NW}$ & NW & W & W & \\
\hline & & & & & . & & & & & & & \\
\hline 5.3 & 14.2 & 12.9 & 13.2 & 14.9 & 11.8 & 11.7 & 13.0 & 15.2 & 17.1 & 14.9 & 15.6 & 14.2 \\
\hline $\mathbf{N}$ & $\mathbf{N}$ & $\mathbf{N}$ & $\mathbf{N}$ & $\mathbf{N}$ & $\mathbf{N}$ & $\mathbf{N}$ & $\mathbf{N}$ & $\mathbf{N}$ & $\mathbf{N}$ & NW & $\mathrm{N}$ & \\
\hline 4.6 & 7.4 & 4.9 & 4.7 & 6.4 & 8.0 & 8.5 & 6.4 & 8.1 & 10.3 & 7.0 & 3.8 & 6.7 \\
\hline NW. & NW & NW & NW & NW & NW & NW & NW & NW & NW & NW & NW & \\
\hline 12.2 & $10: 5$ & 9.2 & 8.7 & 8.5 & 8.5 & 9.6 & 10.0 & 11.0 & 12.0 & 11.0 & 10.3 & 10.1 \\
\hline sw & W & sw & $w$ & $\mathbf{W}$ & $\mathbf{N}$ & NE & $\mathrm{NE}$ & $\mathbf{N}$ & SW & W & SW & \\
\hline 12.1 & 12.3 & 10.5 & 13.1 & 13.2 & 12.3 & 12.2 & 12.9 & 13.3 & 13.3 & 13.2 & 13.3. & 12.6 \\
\hline NW & $\mathbf{N}$ & $\mathbf{N}$ & $\mathbf{N}$ & NW & $\mathbf{N}$ & $\mathbf{N}$ & $\mathbf{N}$ & $\mathbf{N}$ & NW & $\mathbf{N}$ & $\mathbf{N}$ & \\
\hline 7.2 & 6.6 & 5.4 & 5.8 & 8.4 & 10.9 & 11.3 & 8.6 & 7.8 & 6.6 & 6.2 & 5.4 & 7.6 \\
\hline $\mathbf{E}$ & $\mathbf{E}$ & $\mathbf{E}$ & $\mathrm{E}$ & NW & NW & NW & NW & NE & $\mathrm{E}$ & $\mathbf{E}$ & $\mathrm{E}$ & \\
\hline 9.1 & 9.5 & 9.7 & 11.0 & 13.4 & 11.7 & 9.7 & 8.9 & 11.5 & 14.6 & 12.3 & 11.0 & 11.0 \\
\hline $\mathrm{NW}$ & NW & NW & NW & NW & $\mathrm{SE}$ & $\mathrm{SE}$ & $\mathrm{SE}$ & NW & NW & NW & NW & \\
\hline 9.1 & 7.9 & 9.5 & 11.5 & 10.3 & 9.5 & 8.7 & 8.9 & 11.7 & 13.1 & 11.6 & 11.2 & 10.3 \\
\hline$E$ & $\mathbf{E}$ & $\mathrm{E}$ & E & $\mathbf{E}$ & $\mathrm{E}$ & w & $\mathrm{E}$ & $\mathrm{E}$ & $E$ & $\mathrm{E}$ & $E$ & \\
\hline 10.6 & 7.9 & 7.0 & 7.5 & 10.3 & 9.9 & 10.9 & 10.0 & 9.9 & 11.0 & 9.0 & 9.7 & 9.5 \\
\hline $\mathbf{N}$ & $\mathbf{N}$ & $\mathbf{N}$ & $\mathbf{N}$ & $\mathbf{N}$ & $\mathbf{N}$ & NW & N. SW & $\mathrm{N}$ & $\mathrm{N}$ & $\mathbf{N}$ & $N, N W$ & \\
\hline & & & & & & & & & - & & & \\
\hline 10.5 & 8.6 & 7.9 & 8.4 & 11.7 & 13.0 & 12.2 & 11.2 & 11.6 & 11.3 & 9.9 & 8.5 & 12.5 \\
\hline NW & NW & $\mathrm{N}$ & N,NW & NW & NW & NW & $\mathrm{S}, \mathrm{NE}$ & NW & NW & $\mathrm{NW}$ & NW & \\
\hline & & 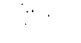 & $\cdot$ & & & & & & & & i: & \\
\hline 10.9 & 11.5 & 9.9 & 11.5 & 11.2 & 10.7 & 9.8 & 11.1 & 10.9 & 14.5 & 13.0 & 11.6 & 11.4 \\
\hline NW & NW & NW & $\mathrm{NE}$ & $\mathrm{NE}$ & $\mathrm{NE}$ & W & $\mathrm{NE}$ & NW & NW & $\mathrm{N}$ & $\mathrm{N}$ & \\
\hline
\end{tabular}

* 2 years only. 
Table XLI (cont'd). Mean windspeed (mph) and direction, Northern Hemisphere.

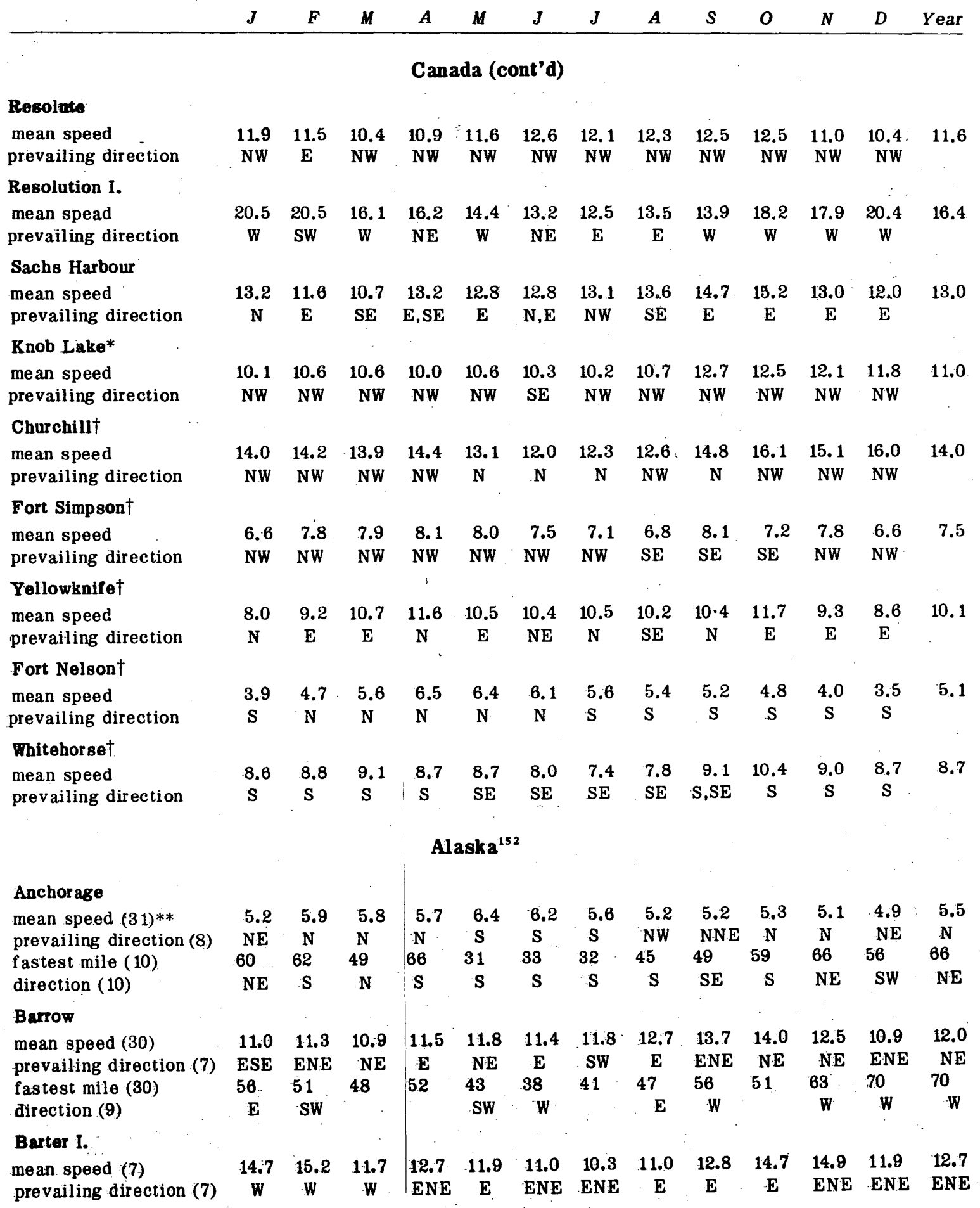

* Average values $1954-62{ }^{127}$ prevailing direction. ${ }^{6}$

$f$ Periods prior to $1951 \cdot 60 .^{6}$

** Number of years of record. 
Table XLI (cont'd). Mean windspeed (mph) and direction, Northern Hemisphere.

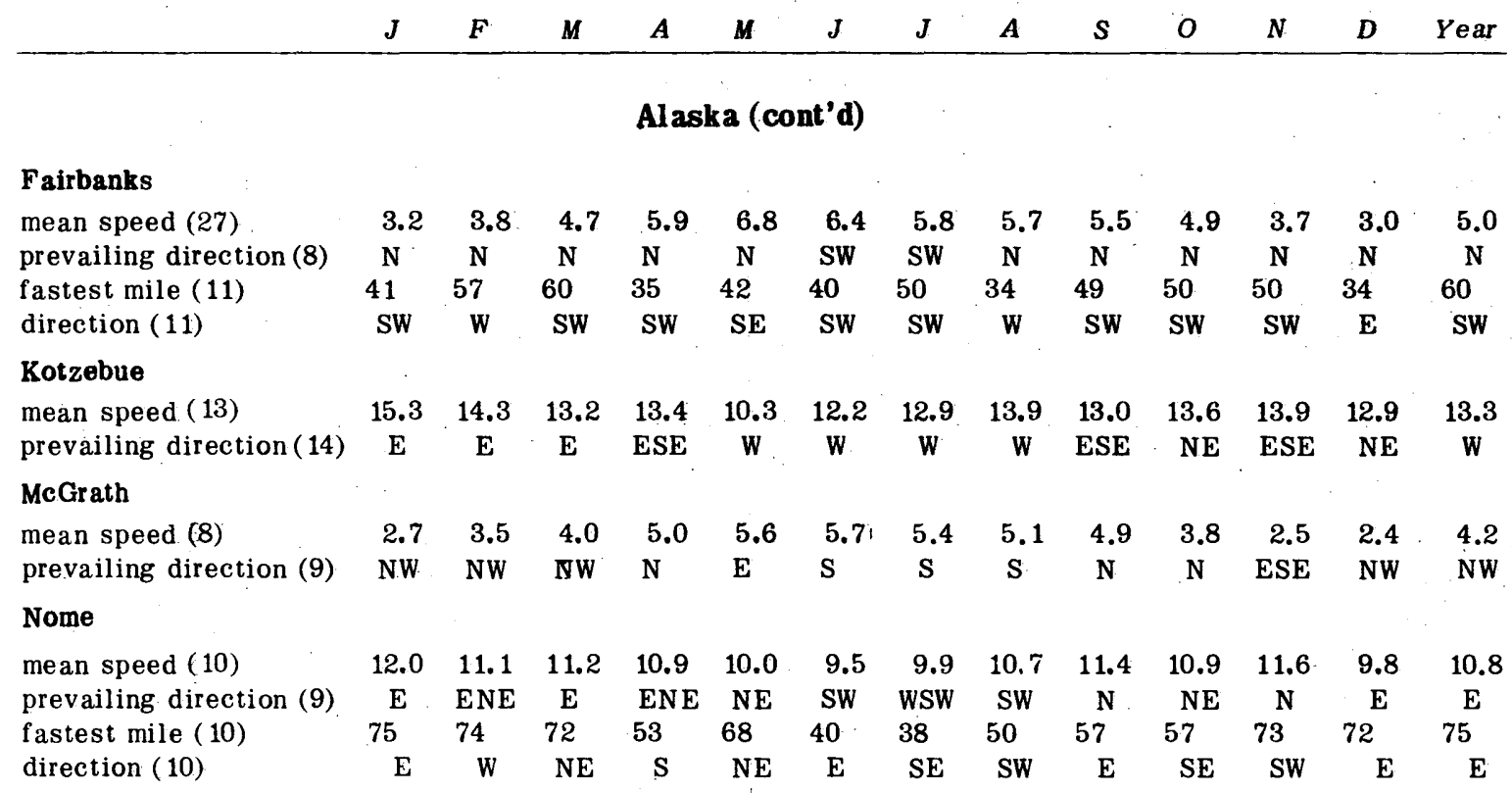

\section{Greenland $^{3} 57$}

Thule

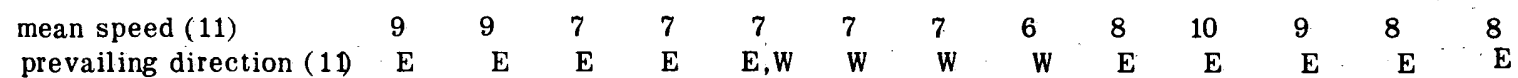

Eismitte

mean speed (2)

Angmags8alik

mean speed (30).

Scoresbysund

mean speed (12)

Nanortalik

mean speed (41)

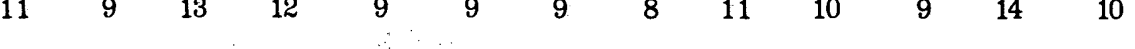

$\begin{array}{lllllllllllll}6 & 6 & 5 & 3 & 3 & 3 & 3 & 3 & 3 & 4 & 5 & 5 & 4\end{array}$

$\begin{array}{lllllllllllll}5 & 5 & 4 & 4 & 3 & 3 & 3 & 3 & 3 & 4 & 4 & 4 & 4\end{array}$

$\begin{array}{lllllllllllll}12 & 11 & 11 & 10 & 7 & 10 & 7 & 6 & 8 & 9 & 10 & 10 & 10\end{array}$

Eurasia $^{98}$

Jan Mayen

$\begin{array}{llllllllllllll}\text { mean speed }(\mathrm{mph}) & 21 & 21 & 18 & 17 & 13 & 14 & 12 & 14 & 16 & 18 & 19 & 18 & 17\end{array}$ no. of days with gales*

Vardo

$\begin{array}{lrrrrrrrrrrrrr}\text { mean speed (28) } & 22 & 21 & 21 & 19 & 16 & 16 & 13 & 14 & 17 & 19 & 21 & 21 & 18 \\ \text { no. of days with gales*(28) } & 5 & 5 & 4 & 3 & 2 & 1 & 1 & 2 & 2 & 3 & 5 & 5 & 38\end{array}$

Ostrov Diksona

mean speed (19)

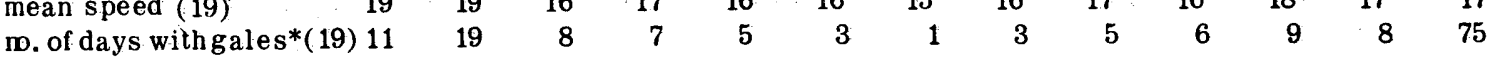

Bukhta Tikhaya

mean speed (10)

no. of days with gales*(10)10

$\begin{array}{rrrrrrrrrrrr}15 & 12 & 12 & 11 & 10 & 8 & 9 & 13 & 15 & 15 & 17 & 13 \\ 9 & 7 & 5 & 3 & 3 & 2 & 2 & 4 & 6 & 8 & 11 & 69\end{array}$

* Gale defined as: windspeed $\geq 32 \mathrm{mph}$. 
Table XLI (cont'd). Mean windspeed (mph) and direction, Northern Hemisphere.

\begin{tabular}{|c|c|c|c|c|c|c|c|c|c|c|c|c|c|}
\hline & $J$ & $F$ & M & $A$ & $M$ & $J$ & $J$ & $A$ & $s$ & 0 & $N$ & $D$ & Year \\
\hline \multicolumn{14}{|c|}{ Gurasia (cont'd) } \\
\hline \multicolumn{14}{|l|}{ Russkoye Ust'ye } \\
\hline mean speed (9) & 8 & 8 & 9 & 9 & 9 & 12 & 12 & $\mathrm{t} 2$ & 11 & 9 & 9 & 9 & 10 \\
\hline no. of days withgales*(9) & $<0.5$ & $<0.5$ & 2 & 1 & .1 & 2 & 2 & 2 & 1 & 2 & 1 & 1 & 15 \\
\hline \multicolumn{14}{|l|}{ Mys Shmidta } \\
\hline mean speed $(3)$ & 13 & 11 & 12 & 11 & 11 . & 11 & 10 & 13 & 14 & 17 & 14 & 12 & 12 \\
\hline no. of days with gales*(3) & 10 & 6 & 8 & 5 & 5 & 4 & 2 & 4 & 5 & 7 & 4 & 8 & 68 \\
\hline \multicolumn{14}{|l|}{ Anadyr' } \\
\hline mean speed (14) & 13 & 14 & 12 & 11 & 9 & 10 & 11 & 11 & 11 & 12 & 13 & 13 & 12 \\
\hline no. of days with gales*(14) & 4 & 4 & 4 & $2:$ & 1 & $<0.5$ & 2 & 1 & 2 & 2 & 4 & 3 & 29 \\
\hline \multicolumn{14}{|l|}{ Verkpoyangk } \\
\hline mean speed $(21)$ & 1 & 2 & 2 & 4 & 6 & 7 & 6 & 5 & 4 & 3 & 2 & 1 & 3 \\
\hline no. of days with gales*(21) & $<0.5$ & $<0.5$ & $<0.5$ & $<0.5$ & 2 & 2 & 1 & 1 & $<0.5$ & $<0.5$ & $\tilde{0}$ & 7 & 17 \\
\hline \multicolumn{14}{|l|}{ Yakutsk } \\
\hline mean speed $(21)$ & 3 & 3 & 3 & 5 & 6 & 5 & 5 & 5 & 4 & 4 & 3 & 3 & 4 \\
\hline no. of days with gales*(21) & $<0.5$ & $<0.5$ & 1 & 1 & 2 & 2 & 1 & 1 & 1 & 1 & $<0.5$ & $<0.5$ & 10 \\
\hline
\end{tabular}

\section{Polar Ocean}

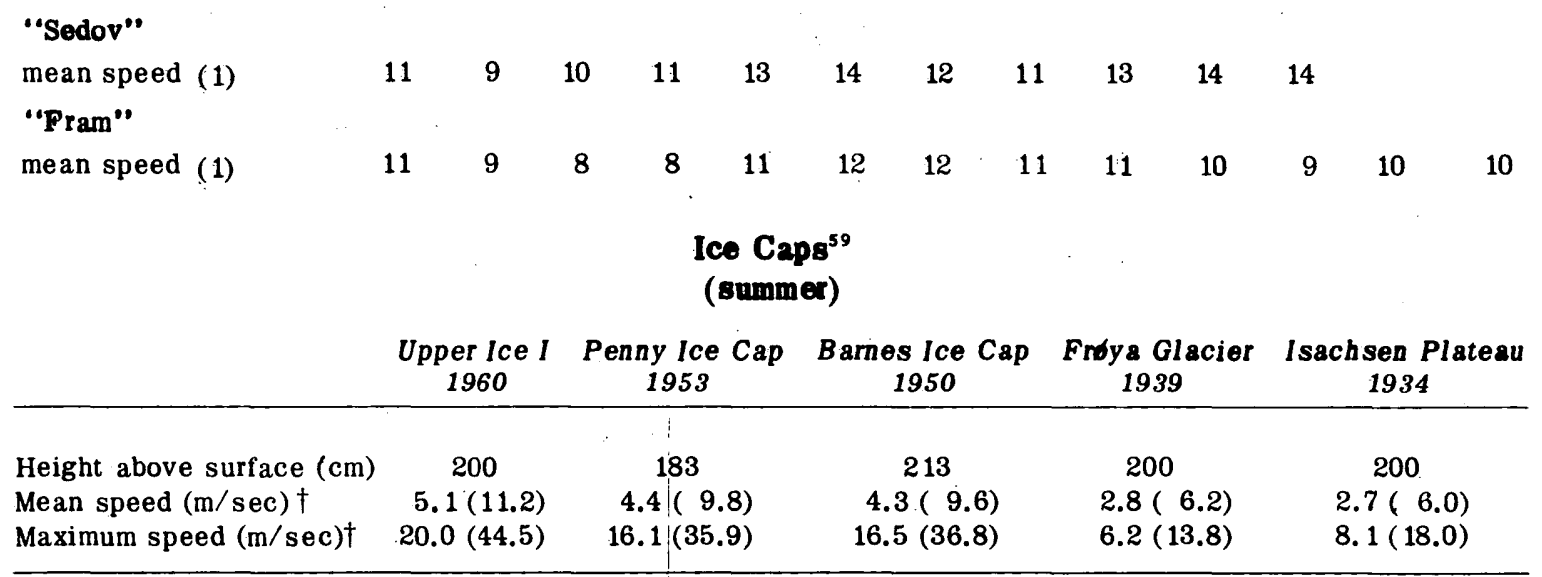

* Gale defined as windspeed $\geq 32 \mathrm{mph}$.

$\dagger$ Mph in parentheses.

Over the Greenland Ice Cap, the mean windspeeds average between 10 and15 mph (4.5 and $6.7 \mathrm{~m} / \mathrm{sec}$ ) for the year. The pressure gradient appears to be the controlling factor in this region as the inversion is comparatively shallow. Months of highest mean windspeeds are associated with those of most intense cyclonic activity, in the autumn and winter. Summer observations over the small ice caps of the Arctic indicate average windspeeds of 6 to $10 \mathrm{mph}(2.7$ to $4.5 \mathrm{~m} / \mathrm{sec})$ (see Table XLI, above).

Observations from the Polar Ocean are sparse, but mean windspeeds appear to be relatively low - the Maud expedition recorded a mean of $9 \mathrm{mph}(4 \mathrm{~m} / \mathrm{sec})$ for the year, and the Fram $10 \mathrm{mph}$ $(4.5 \mathrm{~m} / \mathrm{sec})$. Cyclonic activity is most intense in the autumn and winter.

There are many exceptions to these major groupings due to the frequency and intensity of the pressure systems, the static stability of the inversion layer and the local topographic factors at each observation site. 
Prevalence of wind direction is a characteristic of many stations in the cold regions. Although basically governed by the frequency of high and low pressure systems, ${ }^{160}$ the prevailing winds closely reflect the influence of the local and regional topography.* The local relief serves to deflect or channel the surface flow into certain preferred paths. The effect of the form and orientation of the coast and channels at stations in the Canadian Archipelago have been discussed by $\mathrm{Rae}^{100}$ (see also Table XLI). Inland at Lake Hazen, under conditions of lighter flow, the influence of the northeast-southwest orientation of the valley is still clearly seen in the wind roses at all seasons ${ }^{66}$ (Fig. 55a). The coastal regions of Greenland ${ }^{3}{ }^{46} 57$ are affected by the downslope katabatic flow of cold air from the ice cap, whose direction locally is related to the orientation and form of the coastal valleys and fjords. The coasts of northern Norway, Alaska, Spitsbergen

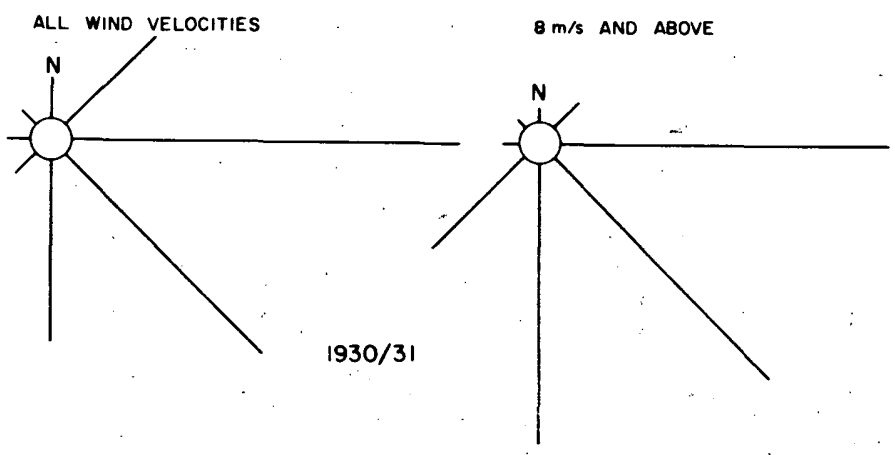

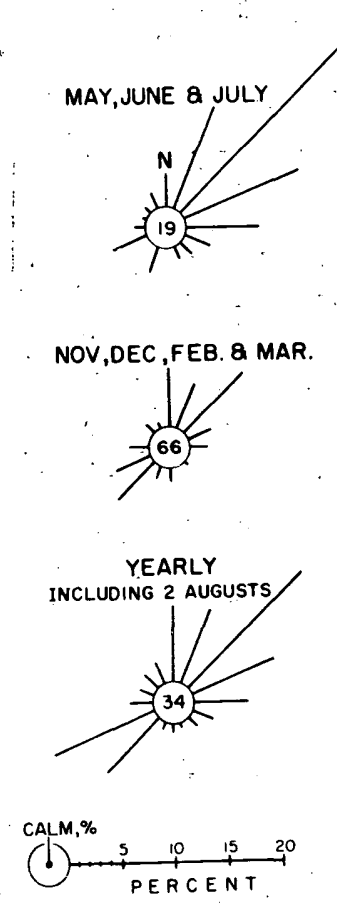

a. Lake Hazen, 1957 i August 1958. ${ }^{66}$
ALL WIND VELOCITIES
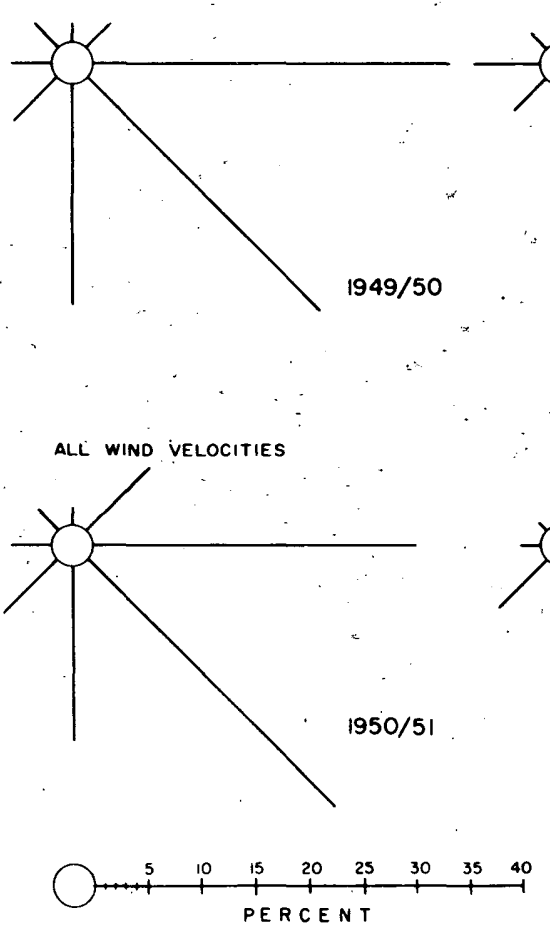

b. Eismitte and Station Centrale, Greenland. ${ }^{101}$

Figure 55. Surface wind roses.

* The local exposure of the station and the instrument has also to be considered. 
and Wrangel Island are similarly affected by downslope components. The surface wind direction at stations on the Greenland Ice Cap, where the slope is slight, is remarkably constant: at Northice prevailing winds are from the west, at Eismitte (Fig. 55b), Site I and Site II, from the eastsoutheast. While the surface flow is closely related to the regional pressure gradient, it includes a katabatic element which becomes evident under conditions of weak pressure gradient..$^{525}$

At certain stations such as Baker Lake, Chesterfield Inlet, Clyde Harbour and Coral Harbour, winds persist from the same preferred direction all year; at other stations, however, a marked seasonal change or even reversal takes place. Such changes are frequently a combination of a shift in the major trajectories and mean centers of the pressure systems and a "monsoonal" effect due to differential heating of land and water/ice. At Thule ${ }^{3}$ (Fig. 55c), the most frequent winds in the cold season are from the ice cap while in the summer months the prevailing direction is from the sea. Many other coastal stations in Greenland show similar changes. At Frobisher Bay ${ }^{145}$ there is a reversal from prevailing northwest winds in winter, associated with the semi-permanent west Greenland trough, to southeast winds in summer, largely associated with the storm track from Hudson Bay. The onshore component is most marked in summer along the northern shore of Siberia (and to a lesser extent in Alaska) where a strong thermal gradient develops between the cold ocean and the heated continental interior. Elsewhere the effects of differential heating alone are not strong enough to influence the prevailing winds at this season.

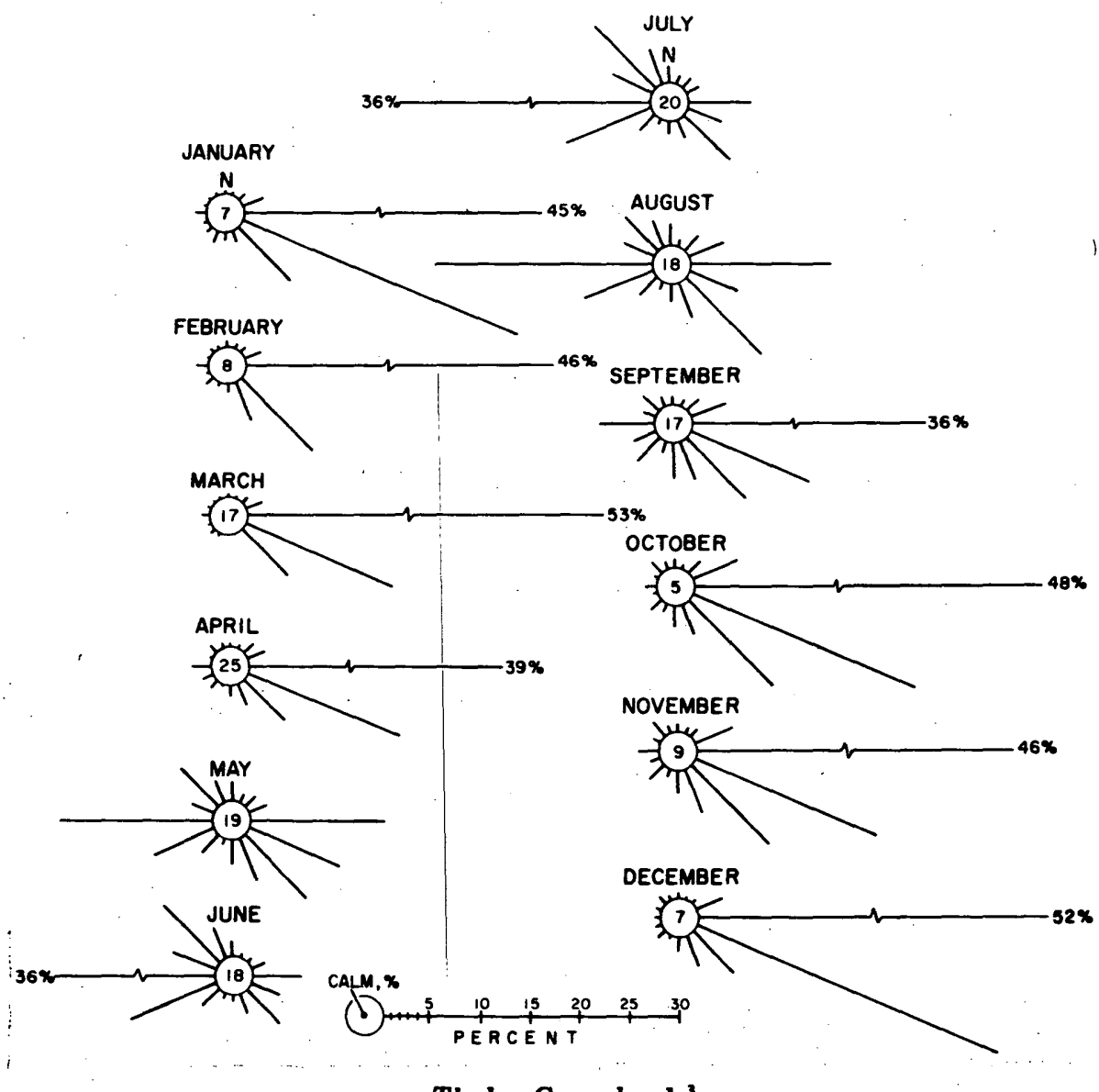

c. Thule, Greenland. ${ }^{3}$

Figure 55 (cont'd). 
Table XLII. Diurnal averages of windspeed (mph) at selected Canadian stations (1953-62). ${ }^{161}$

\section{Whitehorse}

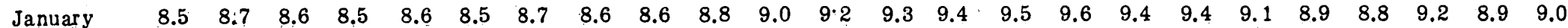

July

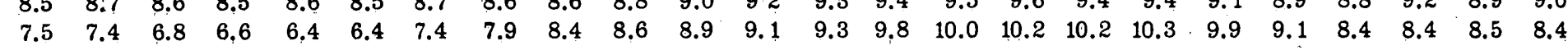

\section{Coral Harbour}

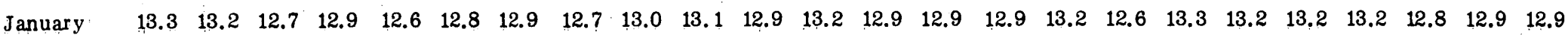
$\begin{array}{llllllllllllllllllllllllll}\text { July } & 9.1 & 9.4 & 9.6 & 10.0 & 10.0 & 10.0 & 10.2 & 10.8 & 11.3 & 11.7 & 12.2 & 13.2 & 13.8 & 14.2 & 14.5 & 14.7 & 15.0 & 14.8 & 13.9 & 13.3 & 12.2 & 10.6 & 9.6 & 9.4\end{array}$

\section{Frobisher Bay}

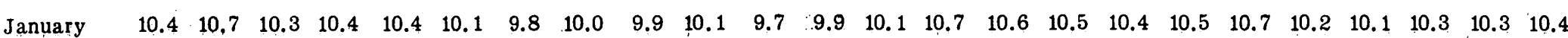
$\begin{array}{llllllllllllllllllllllllll}\text { July } & 7.0 & 6.7 & 6.9 & 6.9 & 6.7 & 7.5 & 8.0 & 8.9 & 9.9 & 10.2 & 11.0 & 11.5 & 11.9 & 11.9 & 12.0 & 12.0 & 11.8 & 11.6 & 11.6 & 10.6 & 9.1 & 8.3 & 7.8 & 7.5\end{array}$

\section{Yellowknile}

$\begin{array}{llllllllllllllllllllllllll}\text { January } & 9.3 & 9.4 & 9.5 & 9.5 & 9.5 & 9.5 & 9.4 & 9.5 & 9.4 & 9.5 & 9.3 & 9.4 & 9.0 & 8.9 & 8.8 & 8.6 & 8.9 & 9.0 & 9.1 & 9.0 & 9.4 & 9.1 & 9.1 & 9.4\end{array}$

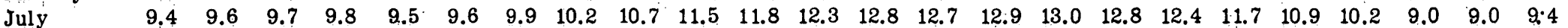

\section{Churchill}

$\begin{array}{lllllllllllllllllllllllll}\text { January } & 15.4 & 15.2 & 15.3 & 15.5 & 15.4 & 15.4 & 15.5 & 15.1 & 14.7 & 15.0 & 15.0 & 14.9 & 15.2 & 15.3 & 15.2 & 15.5 & 15.5 & 15.5 & 16.2 & 16.0 & 15.6 & 15.7 & 15.5 & 15.4\end{array}$ $\begin{array}{lllllllllllllllllllllllllll}\text { July } & 13.2 & 12.9 & 12.7 & 12.8 & 12.6 & 12.3 & 12.6 & 12.9 & 12.8 & 12.8 & 12.7 & 13.0 & 13.6 & 13.4 & 13.4 & 13.2 & 13.1 & 12.6 & 12.5 & 12.2 & 12.0 & 12.6 & 12.7 & 12.7\end{array}$

\section{Sept nes}

$\begin{array}{lllllllllllllllllllllllllll}\text { January } & 13.1 & 13.0 & 13.1 & 13.0 & 12.9 & 12.7 & 12.5 & 12.7 & 13.2 & 13.3 & 13.6 & 13.9 & 13.9 & 13.7 & 14.1 & 13.7 & 13.0 & 12.7 & 13.1 & 12.9 & 12.9 & 13.2 & 13.1 & 13.3\end{array}$ $\begin{array}{lllllllllllllllllllllllll}\text { July } & 7.8 & 7.9 & 7.8 & 7.8 & 7.4 & 7.5 & 7.9 & 8.4 & 9.0 & 10.7 & 11.7 & 12.2 & 12.6 & 12.7 & 13.0 & 12.6 & 12.2 & 11.5 & 10.5 & 9.0 & 8.1 & 7.8 & 7.8 & 7.9\end{array}$

\section{Goose}

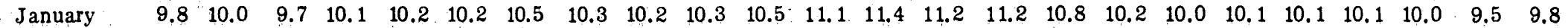

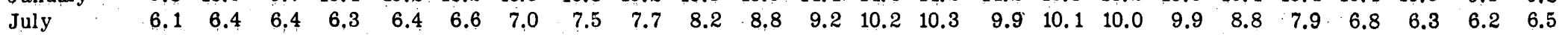




\section{Diurnal distribution}

In general, diurnal variation of windspeed is related to stability, and the values are lowest at night. At northern stations there is little diurnal effect in the cold months, although stations which experience katabatic winds may record a nocturnal maximum, with minimum in the afternoon. In the northern summer, land and sea breeze effects are seldom as well developed at arctic stations as at stations further south, partly owing to the length of day. At interior stations, heating in the valleys may give rise to daytime anabatic (up valley) flow under weak pressure gradients. $^{715}$

At subarctic stations, there can be considerable diurnal variation in summer. Table XLII lists the monthly average of hourly windspeeds for a 10 -year period at selected Canadian stations. There is little daily change in speed in January, but in July there can be as much as 4 to $6 \mathrm{mph}$ ( 2 to $3 \mathrm{~m} / \mathrm{sec}$ ) difference in the mean between the nocturnal minimum and afternoon maximum. Churchill alone shows little periodic variation.

\section{Maximum Windspeeds and Prevailing Direction}

\section{Distribution}

Surface windspeeds in the Arctic and mid-latitudes in winter are about 30 to $60 \%$ those of the pressure gradient speed, when values are above $4 \mathrm{mph}(2 \mathrm{~m} / \mathrm{sec})$, owing to the drag of the earth's surface. In summer, speeds may average 60 to $70 \%:{ }^{107}$. The seasonal differences reflect the differences in static stability of the lower layers of the atmosphere. An outstanding feature of the strongest winds at many arctic stations is that they are super-gradient, indicating that the flow set up by the pressure gradient is being reinforced by local or regional effects of terrain. Such maximum winds generally show a preferred direction, which may be different from that of the prevailing wind at the station. Studies of such local winds suggest that their occurrence is related to strong pressure gradients in the middle and upper troposphere which are favorably aligned with respect to local or regional topography so that the surface winds are accelerated by flow over or around barriers, by funneling and channeling or by the addition of a katabatic (downslope) component. At some locations, more than one of these factors is in operation during high winds. These terrain effects are generally more pronounced in winter, when the air is stable.

Figure 56 shows the mean percent frequency of winds* over $24 \mathrm{mph}(11 \mathrm{~m} / \mathrm{sec})$ in the Arctic during December-January-February ${ }^{58}$ The highest frequency of strong winds occurs along the coasts of the Norwegian and Barents Seas, on neighboring islands, and along the Pacific and Atlantic coasts. These are the regions of maximum storminess and least vertical stability. Along the shores of the Arctic Ocean, the North American sector contrasts strongly with the more windy Siberian coast. A contrast is also seen between the west and east coasts of Greenland. The regions of minimum values are the continental interiors of northwestern North America and eastern and central Siberia, where weak pressure gradients and the pooling of cold air militate against high windspeeds. In summer, ${ }^{\text {ss }}$ the general pattern of frequency remains the same, but the percentage drops to about $10 \%$ along the Siberian/European coast and over the Arctic Basin, with values at about $5 \%$ or less on the North American side.

The low percentage of high winds in many coastal or elevated areas of greater vertical stability is deceptive. Although such stations show a high percentage of calms and light winds (less than $10 \mathrm{mph}(4.5 \mathrm{~m} / \mathrm{sec})$ ), when gales do occur they often prevail for 2 or 3 days and are a major hazard to operations and maintenance.

Local studies of surface winds have been made at a number of northern stations in North America and Greenland.

* Frequency tables and graphs of surface winds for North American, Greenland and Eurasian stations have been published in references 102,103 and 140 . 


\section{Selected references}

3. Andrews, R.H. (1964) Meteorology and heat balance of the ablation area, White Glacier (Canadian Arctic Archipelago - summer 1960). Axel Heiberg Island Research Reports, Meteorology, no. 1, McGill University, Montreal.

6. Badigin, K.S. and Zubov, N.N. (1940) Na Korable "Georgi Sedov" cherez Ledovityi Okean (On the "Georgi Sedov" across the Arctic Ocean). Izdat. Glavsev., Moscow.

7. Baldwin, H.I. (1956, 1957) The effect of the forest on snow cover. Proceedings of the Eastern Snow Conference, p. 18-23 (cf., Snow interception by forest, Proceedings of 1963 conference).

11. Bennett, I. (1961-1962) Glaze storms and their economic effects. Proceedings of the Eastern Snow Conference, p. 9-24.

15. Borisov, A.A. (1965) Climates of the U.S.S.R. Translated by R.A. Ledward. Chicago: Aldine Publishing Co.

46. Chapman, L.J. (1953) The climate of northern Ontario. Canadian Journal of Agriculture and Science, vol. 33 , no. 1, p. 41-73.

52. Danske Meteorologiska Institut (1958) Summaries of weather observations at weather stations in Greenland, 1949-1953. Charlottenlund.

53. DePercin, F.; Falkowski, S. and Miller, R.C. (1955) Handbook of Big Delta, Alaska, environment. Headquarters, Quartermaster Research and Engineering Command, Natick, Mass., Technical Report EP-5.

57. Diamond, M. (1956) Precipitation trends in Greenland during the past 30 years. USA SIPRE Research Report 22.

58. Diamond, M. (1956, 1957) Vehicular trafficability of snow. Proceedings of the Eastern Snow Conference, p. 54-67.

59. Diamond, M. (1958) Air temperature and precipitation on the Greenland Ice Cap. USA SIPRE Research Report 43.

66. Falkowski, S.J. (1957) Climatic analogues of Fort Greely, Ala ska, and Fort Churchill, Canada, in Eurasia. Headquarters, Quartermaster Research and Engineering Command; Natick Mass., Technical Report EP-77.

77. Georgi, J. (1935) Die Eismittestation. Wis sen schaftliche Ergebnisse der deutschen Grönland Expedition Alfred Wegener, Abt. IV. Leipzig.

78. Georgi, J. (1959) Das Klima des Nordgrönlandi schen Inlandeises. Annalen der Meteorologie, vol. 8, H. 9/10, p. 259-264.

98. Havens, J.M. (1964) Meteorology and heat balance of the accumulation area, McGill Ice Cap, Canadian Arctic Archipelago - summer 1960. Axel Heiberg Island Research Reports. Meteorology, no. 2, McGill University.

100. Hedine, L.J.C. (1946) The arctic whiteout. Bulletin of the American Meteorological Society, 27, p. 130 .

101. Henry, D.M. (1965) Possible precipitation changes resulting from the proposed Rampart Dam Reservoir. USA CRREL Technical Report 147.

102. Hershfield, D.M. and Wilson, W. T. (1957) Generalizing of rainfall-intensity-frequency data. International Association of Scientific Hydrology, General Assembly, Toron to, vol. 1, p. 499-506.

103. Hershfield, D.M. (1961) Estimating the probable maximum precipitation. Journal of the Hydraulics Division, Proceedings ASCE, 87, HY5, p. 99-116.

107. Hogue, D.W. (1958) Significant environmental contrasts of the Thule and Narsarssuak, Greenland areas. Headquarters, Quartermaster Research and Engineering Command, Natick, Mass., Research Study Report RER-23. 
127. Kudryavtsev, V.A. (1959) Temperature, thickness and discontinuity of permafrost. In Principles of geocryology, Part I, Chap. 8, p. 219-273. National Research Council, Canada, Technical Translation 1187, 1965.

140. Lindholm, F. (1955) Sunshine and cloudiness in Sweden, 1901-1930. Geografiska Annaler, 37 , p. 1.50 .

145. Mee, T.R. and Eadie, W.J. (1963) An investigation of specialized whiteout seeding procedures. USA CRREL Research Report 124.

152. Mohn, H. (1907-1930) Report on the scientific results of the Second Norwegian Arctic Expedition in the Fram, 1898-1902. Christiana.

160. Orvig. S. (1954) Glacial meteorological observations on icecaps in Baffin Island. McGill University, Ph.D. Thesis.

161. Petterssen, S. (1956) Weather analysis and forecasting. New York: McGraw-Hill, vol. 2, 2nd ed.

162. Petterssen, S.; Jacobs, W.C. and Haynes, B.C. (1956) Meteorology of the Arctic. Chief of Naval Operations for Polar Projects, OPNAV P03-3, Washington, D.C. 


\section{APPENDIX D. EXCERPT FROM PROCEEDINGS OF THE ARCTIC BASIN SYMPOSIUM OCTOBER 1962}

\section{June 1963}

Held at Hershey, Pa., under the auspices of The Arctic Institute of North America and the Office of Naval Research, U.S. Navy 


\section{Surface Winds}

At middle latitudes the turbulence generated by friction between the wind and the surface of the earth decreases with height and vanishes usually at a height of 2,000 feet. This height increases with lapse rate, surface roughness, and wind speed and may vary under extreme conditions from a few feet to 10,000 feet. In the Arctic, because of the prevailing stability, the friction layer is usually much less than 2,000 feet thick.

The ratio of the speed at the anemometer level to the speed at the top of the friction layer increases with lapse rate and decreases with roughness. With a positive lapse rate and a smooth surface the ratio may be as high as 0.8 but with a very stable lapse rate and rough ground the ratio may be lower than 0.3 .

If the wind speed at a given level near the surface and the lapse rate are known, the speed at a higher level within the friction layer may be calculated by use of a simple formula,

$$
\frac{V_{2}}{V_{1}}=\left(\frac{Z_{2}}{Z_{1}}\right)^{m}
$$

where $m$ varies inversely with lapse rate and has a value of $1 / 7$ for a neutral lapse rate and a maximum possible value of unity for extreme stability.

The angle between the direction of flow near the surface and at the top of the friction layer depends only on stability. The surface deflection is usually less than 10 degrees for a steep lapse rate and near 45 degrees for very stable air.

Where there are hills or ridges near the observing site, the flow is likely to be deformed to some degree, particularly if the air is stable. Unfortunately the theory of flow around or over an obstacle is so complicated that no satisfactory theoretical treatment has been developed.

Several important distortions may be explained simply although incompletely by reference to continuity or the principle of conservation of mass, as expressed by:

$1 \mathrm{u}=$ const

where 1 is the separation of streamlines, and

$u$ is the wind speed.

Thus where the stream lines converge horizontally to pass around an obstacle, the wind increases, and it may be shown that the maximum speed is twice that of the undisturbed flow. This has been termed the corner or promontory effect. Similarly the increase of speed that one would expect because of vertical contraction over a ridge may be described as the crest effect.

When an airstream of stable air climbs over a ridge, buoyancy opposes the climb but assists the descent. Thus the wind speed is less than in the undisturbed flow over the windward slope but is greater down the lee slope. In this circumstance the wind is accelerated to the left on the upstream side and to the right on the downstream side. For this reason the winds tend 


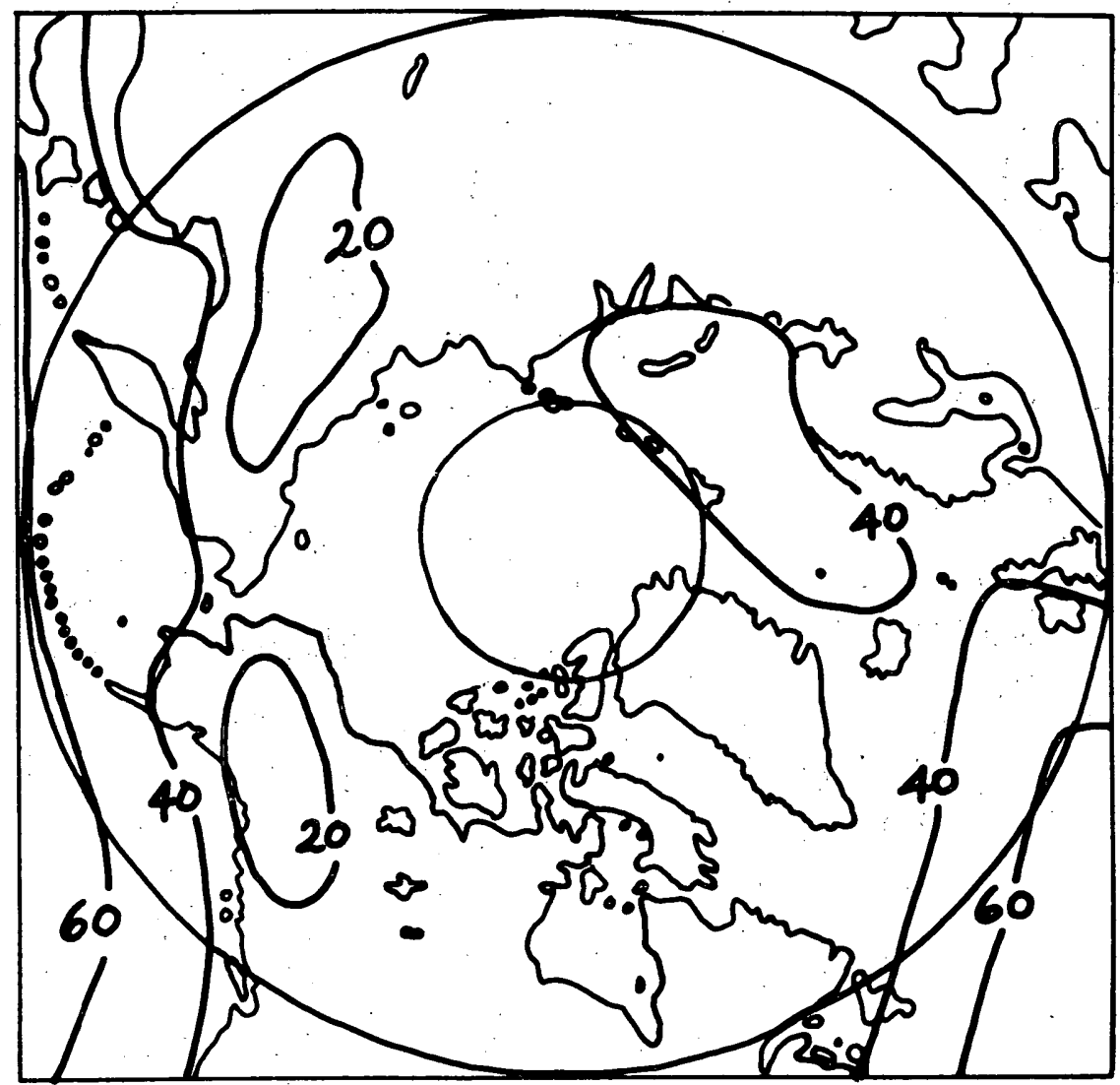

Froure 2 Summer lag in days.

to be anticyclonic around an island and cyclonic around a bay or strait, particularly where the terrain has a steep slope along the coast.

Differences in the rate of heating or of cooling over an area may result in a local distortion of the flow. When a horizontal temperature gradient develops, a horizontal pressure gradient results which causes a wind to blow from cold to warm. For example, in temperate latitudes, the flow is from sea to land and up a slope during day heating and in the opposite direction at night. In the Arctic, because of the dominance of the annual temperature cycle over the diurnal, the thermally induced winds tends to reverse directions seasonally rather than daily.

Coriolis Force

If a perfectly round steel ball is placed on a flat but tilted surface, it will move in the direction of greatest slope. Intuitively one would expect a parcel 


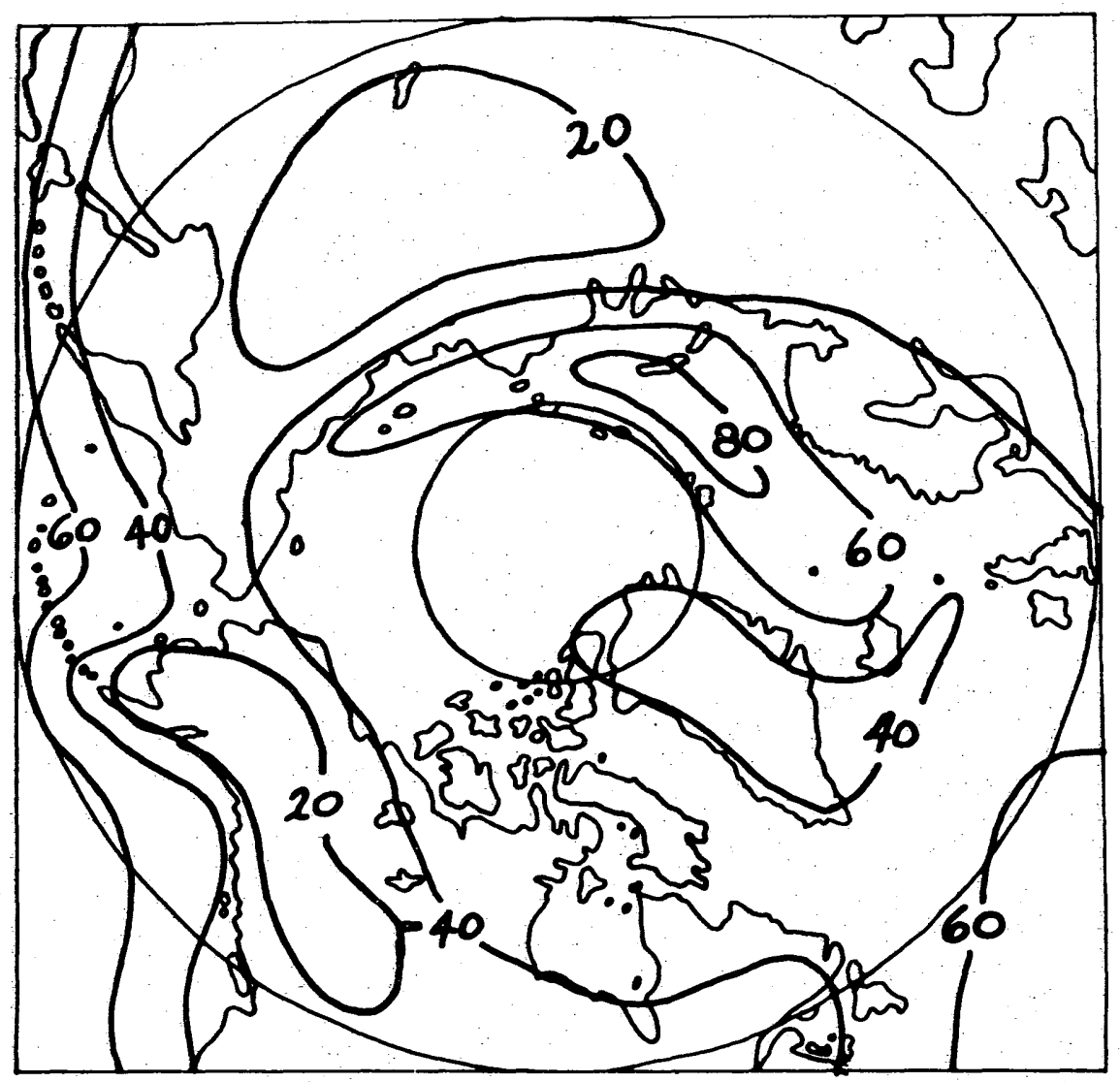

Froure 3 Winter lag in days.

of air to behave similarly by moving directly across the isobars on a weather map towards lower pressures, but instinct is wrong in this case as it fails to take into account the influence of the rotation of the earth, which causes an acceleration to the right for every moving parcel or particle in the northern hemisphere and to the left in the southern.

Actually the coriolis force is usually negligible for motions requiring only minutes for completion, but when time extends into hours, it is of major significance.

\section{The Geostrophic Wind}

A state of steady flow requires an exact balance between the coriolis and pressure gradient forces. This may be represented by a simple vector diaRram. 


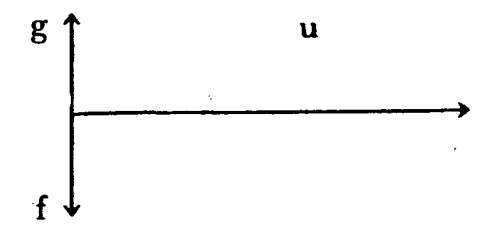

Figure 4. The Balance of forces for a Geostrophic Wind

where $g$ represents the magnitude and direction of the pressure gradient force,

$f$ the coriolis force, and

$u$, the wind speed.

As the coriolis force is proportional to the wind speed, if the wind speed is less than geostrophic, the coriolis force is weaker than the pressure gradient force and the wind must have a compound towards lower pressure. Similarly a super-gradient wind has a component towards higher pressure. 
DOCUMENT CONTROL DATA - R \& D

(Security classification of title, body of abstract and indexing annotation must be ontered when the overall report is clasaifled) 1. ORIGINATING ACTIVITY (Corporate author)

U.S. Army Cold Regions Research and

Engineering Laboratory

Hanover, New Hampshire 03755

3. REPORT TITLE

PREVAILING WIND DIRECTIONS IN THE ARCTIC OCEAN

4. DESCRIPTIVE NOTES (TYPO of roport and Inclusive dates)

8. AU THOR(S) (First name, middlo Initial, laot namo)

Michae1 A. Bile11o

\begin{tabular}{|c|c|c|}
\hline $\begin{array}{l}\text { 6. REPORT DATE } \\
\text { March } 1973\end{array}$ & $\begin{array}{l}\text { 70. TOTAL NO. OF PAGES } \\
38\end{array}$ & $\begin{array}{c}\text { 7b. NO. OF REFS } \\
10\end{array}$ \\
\hline $\begin{array}{l}\text { Ba. CONTRACT OR GRANT NO. } \\
\text { ARPA ORder } 1615 \\
\text { b. PROJECT NO. }\end{array}$ & $\begin{array}{l}\text { 9a. ORIGINATOR'S REPORT } \\
\text { Research Report }\end{array}$ & ER(S) \\
\hline $\begin{array}{l}\text { c. } \\
\text { d. }\end{array}$ & $\begin{array}{l}\text { Ob. OTHER REPORT NO(S) ( } \\
\text { this roport) }\end{array}$ & her numbere that may be acelened \\
\hline
\end{tabular}

10. DISTRIOUTION STATEMENT

Approved for public release; distribution unlimited

11. SUPPLEMENTARY NOTES

12. SPONSORING MILITARY ACTIVITY
Advanced Research
Projects Agency
A 40 Wilson Blvd 22209
Arling ton, Va.

Prevailing monthly and seasonal surface wind directions were obtained from 1) weather records for 21 coastal stations around the Arctic Ocean and 2) a series of U.S. Navy wind charts for 15 to 20 locations in the arctic marginal seas and the ocean's interior. This information was combined and analyzed to develop 2 charts which depict the surface flow of air in these areas during the mid-summer and mid-winter months. Since the ice floe stations used in the offshore wind analysis are not permanently located, the Arctic Ocean was selectively divided into 6 zones. Three of these zones separate Polar regions north of $84^{\circ} \mathrm{N}$ latitude, and 3 other zones each separate the seas bordering the north coasts of Europe, Siberian Russia and North America. Except for a few stations where wind directions are apparently controlled by local influences the results showed the following mid-winter patterns: 1) a near anticlockwise flow within the circle north of $75^{\circ} \mathrm{N}, 2$ ) winds from the north in and near the Chukchi and Bering Seas, 3) northeast winds along the Alaskan coast and northwest along the Canadian Archipelago Islands, and 4) southwest and southeast winds along the northern coasts of Europe and Asia respectively. Although the wind directions during midsummer become more variable the study showed that the prevailing surface winds for most areas in this season are nearly opposite those observed in winter.

14. Key Words

Wind direction Wind measurement Wind (meteorology)
Arctic regions

Polar regions

Meteorological charts
Meteorological data 


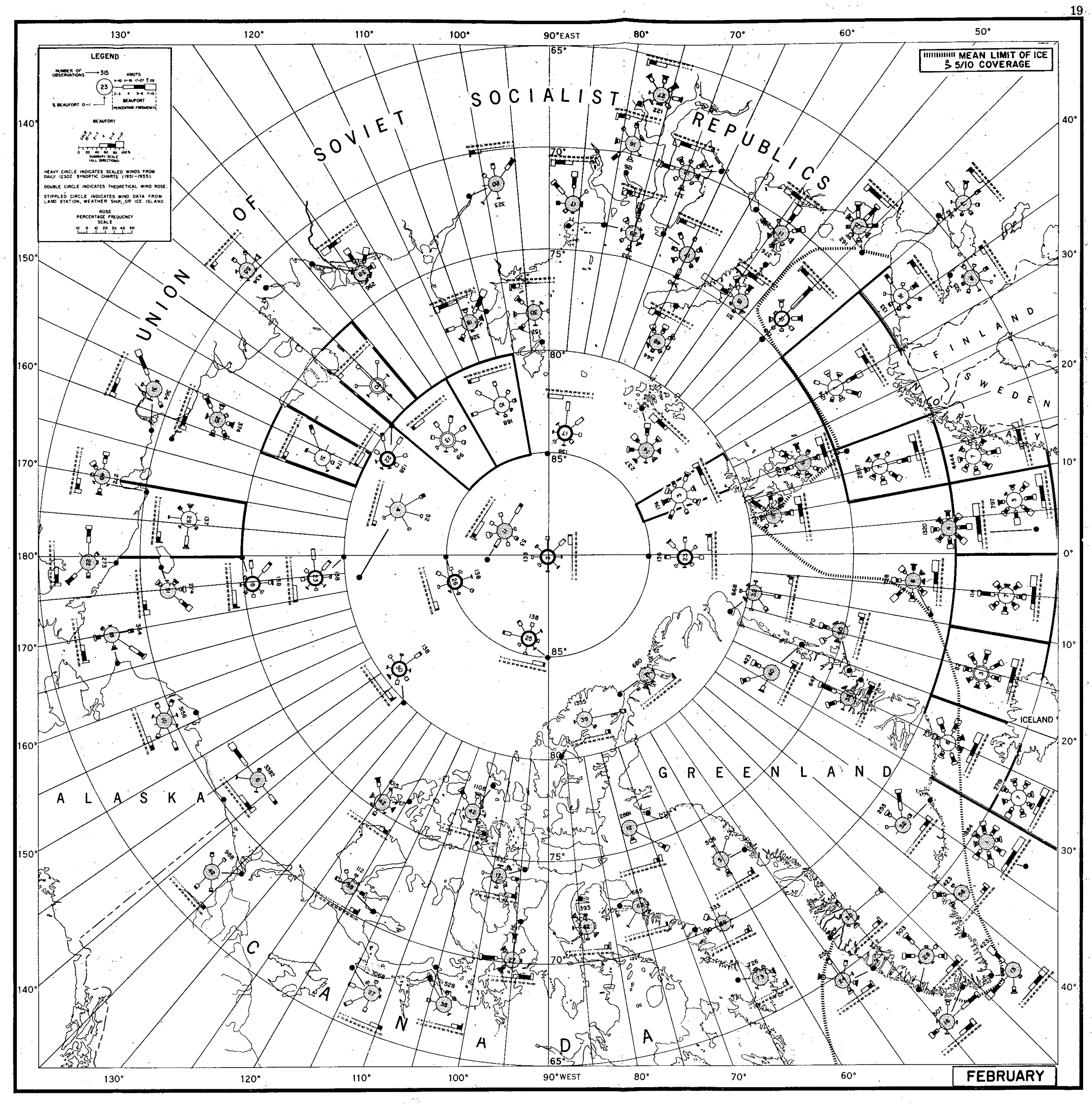

FIG. A1 SURFACE WIND ROSES, FEBRUARY 


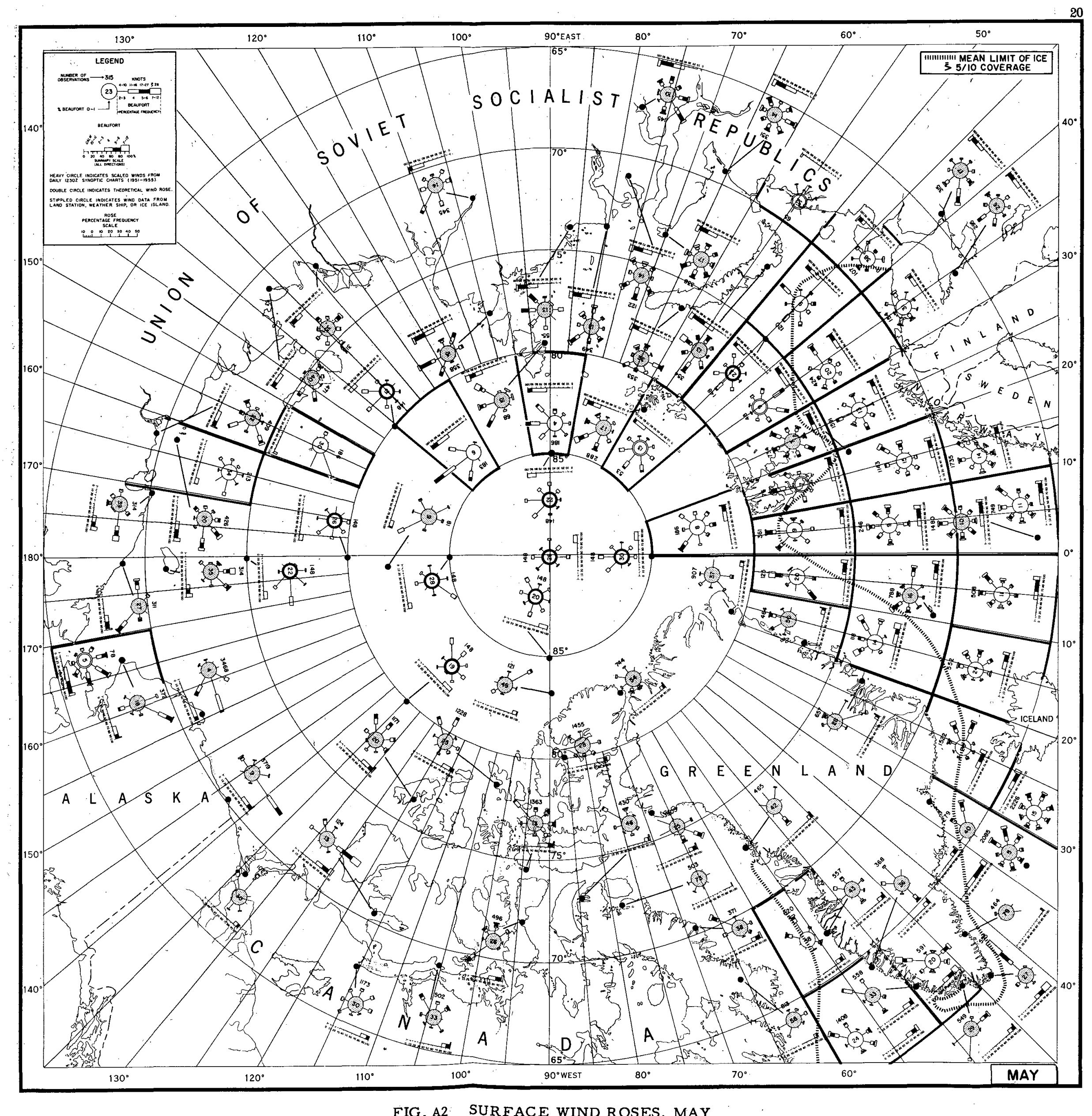

FIG. A2 SURFACE WIND ROSES, MAY 


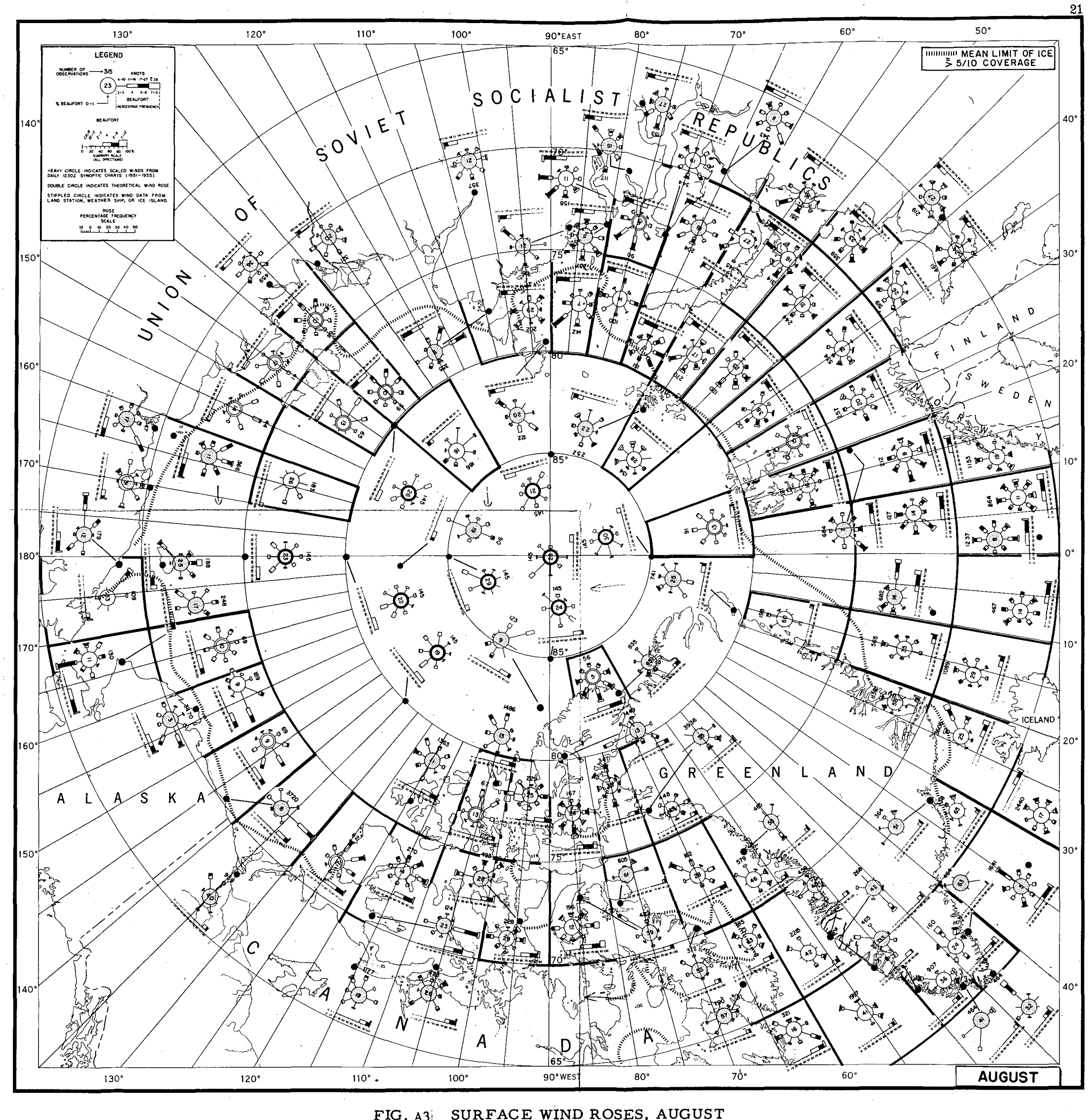




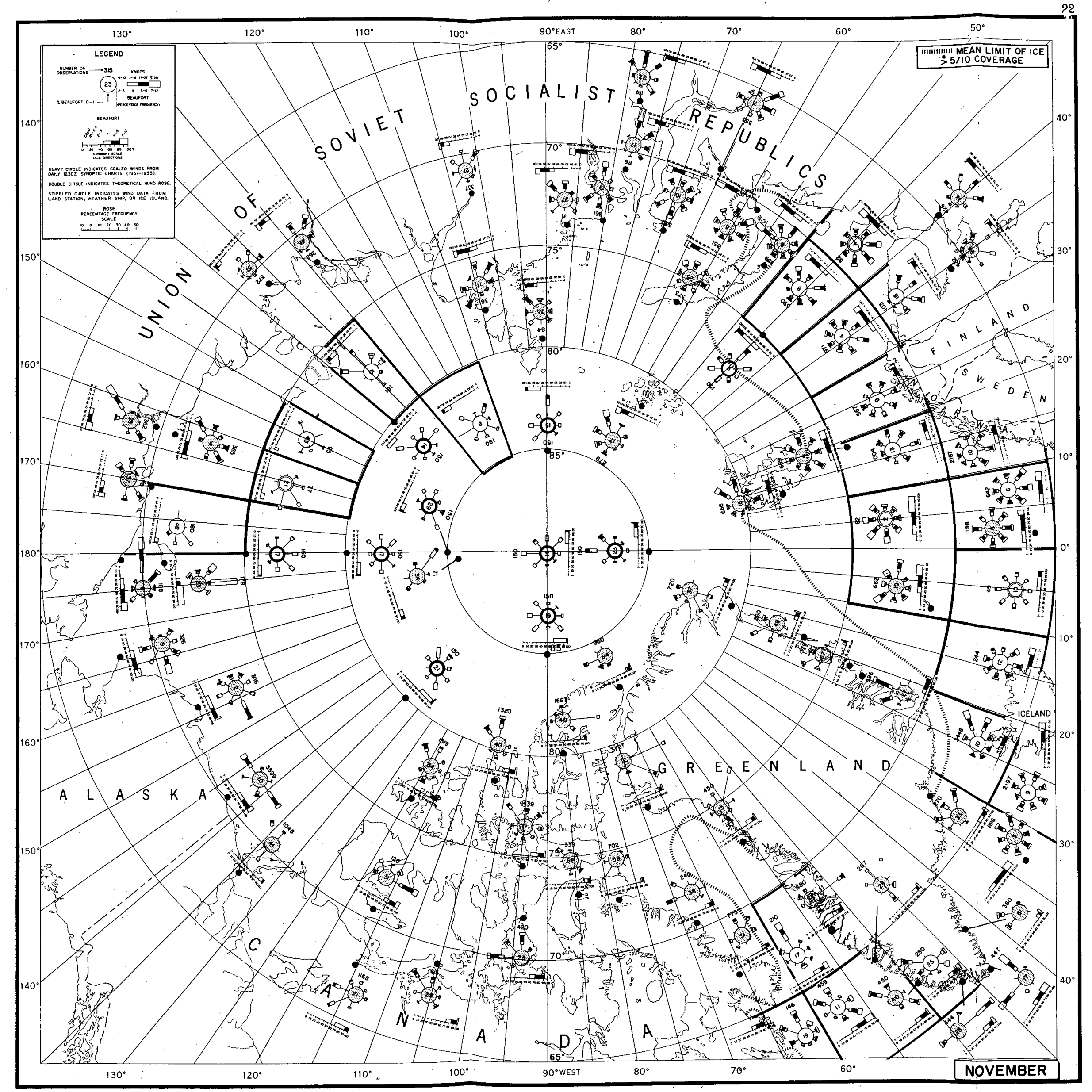

FIG. A4 SURFACE WIND ROSES, NOVEMBER 
APPENDIX B. ARCTIC SURFACE WINDS

From U.S. Navy, 1963, Marine Climatic Atlas of the World, Volume VI, Arctic

Ocean, NAVWEPS 50-IC-533, Chief of Naval Operations, Washington, D.C.

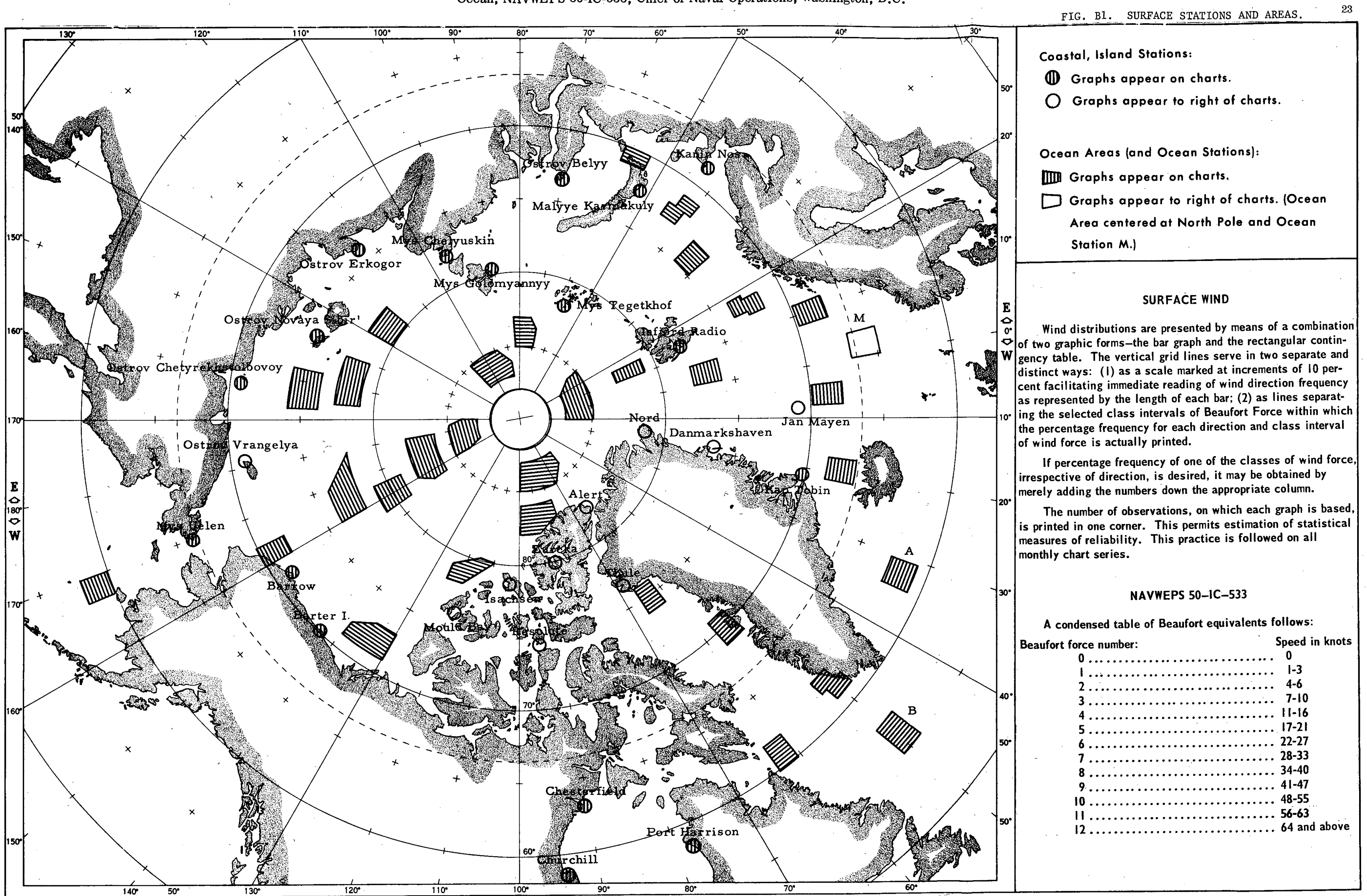




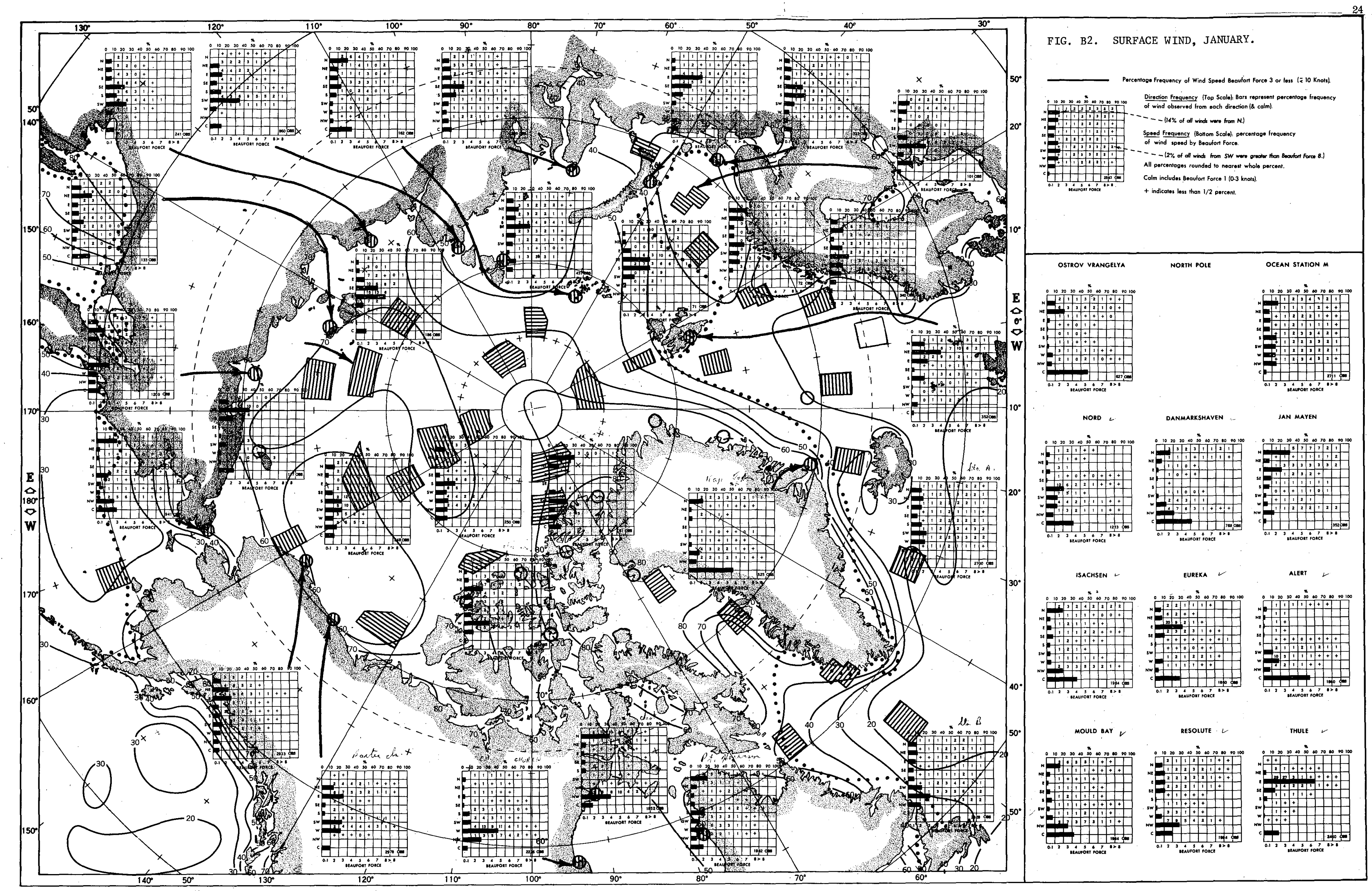




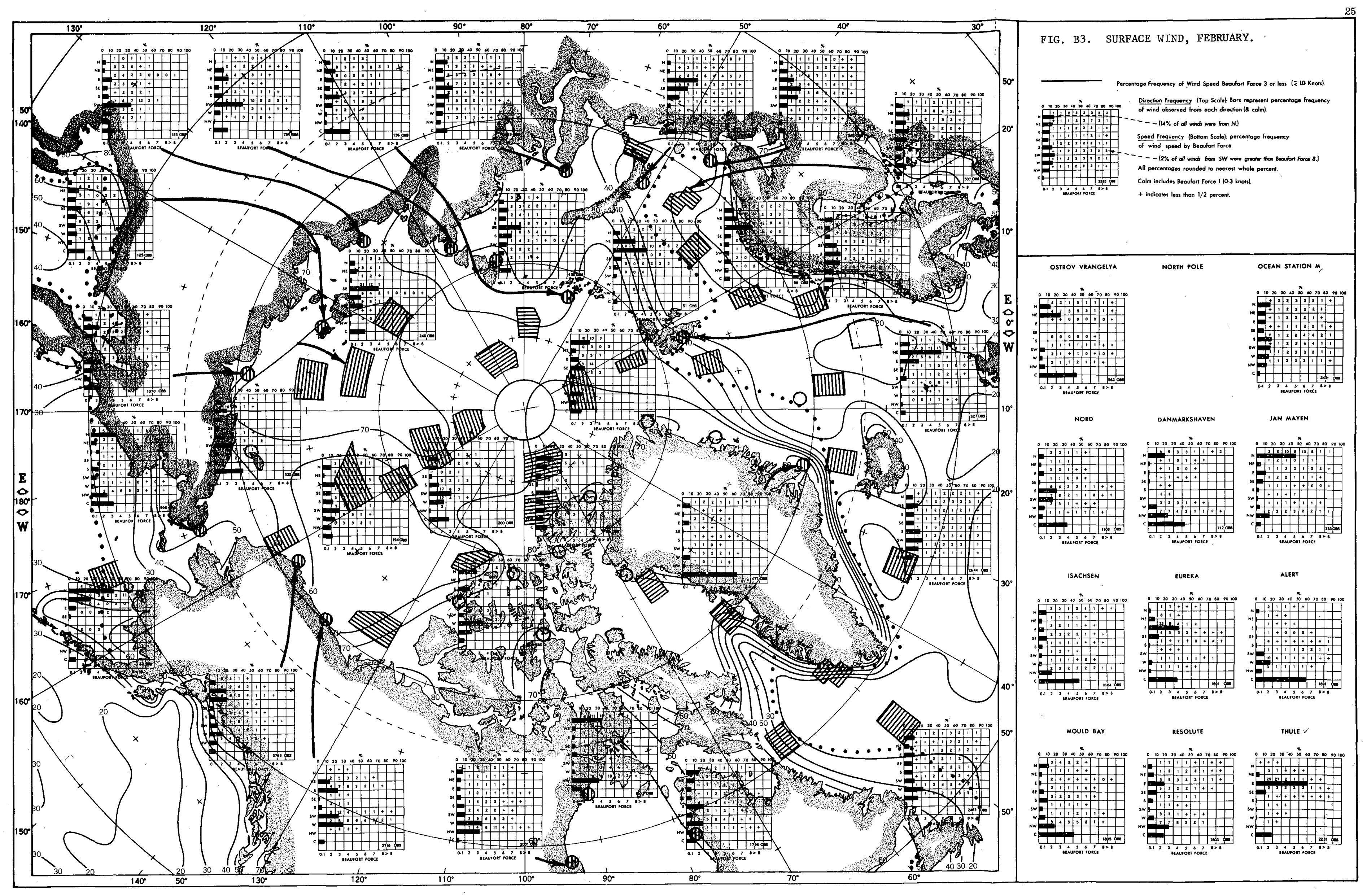




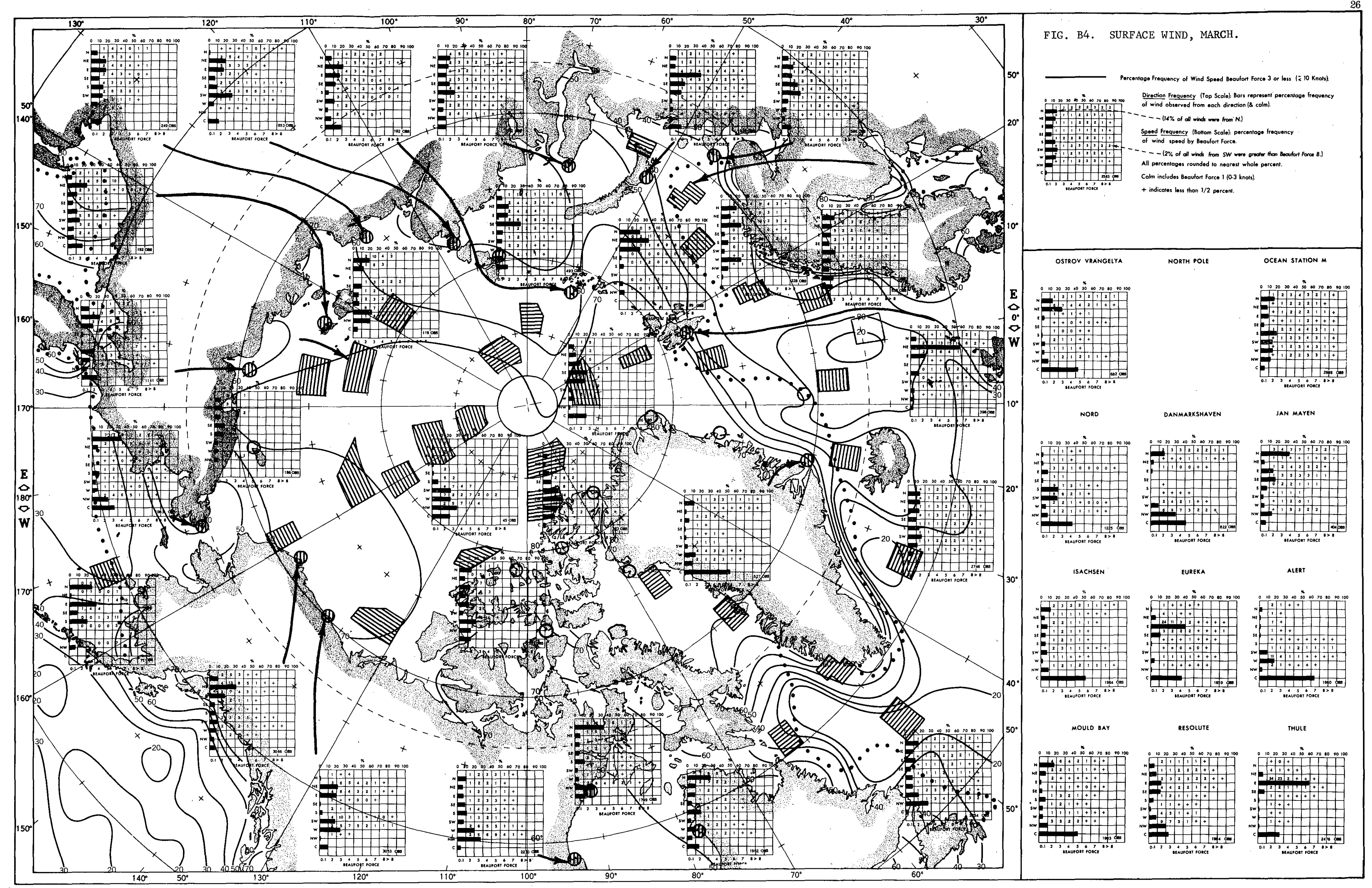




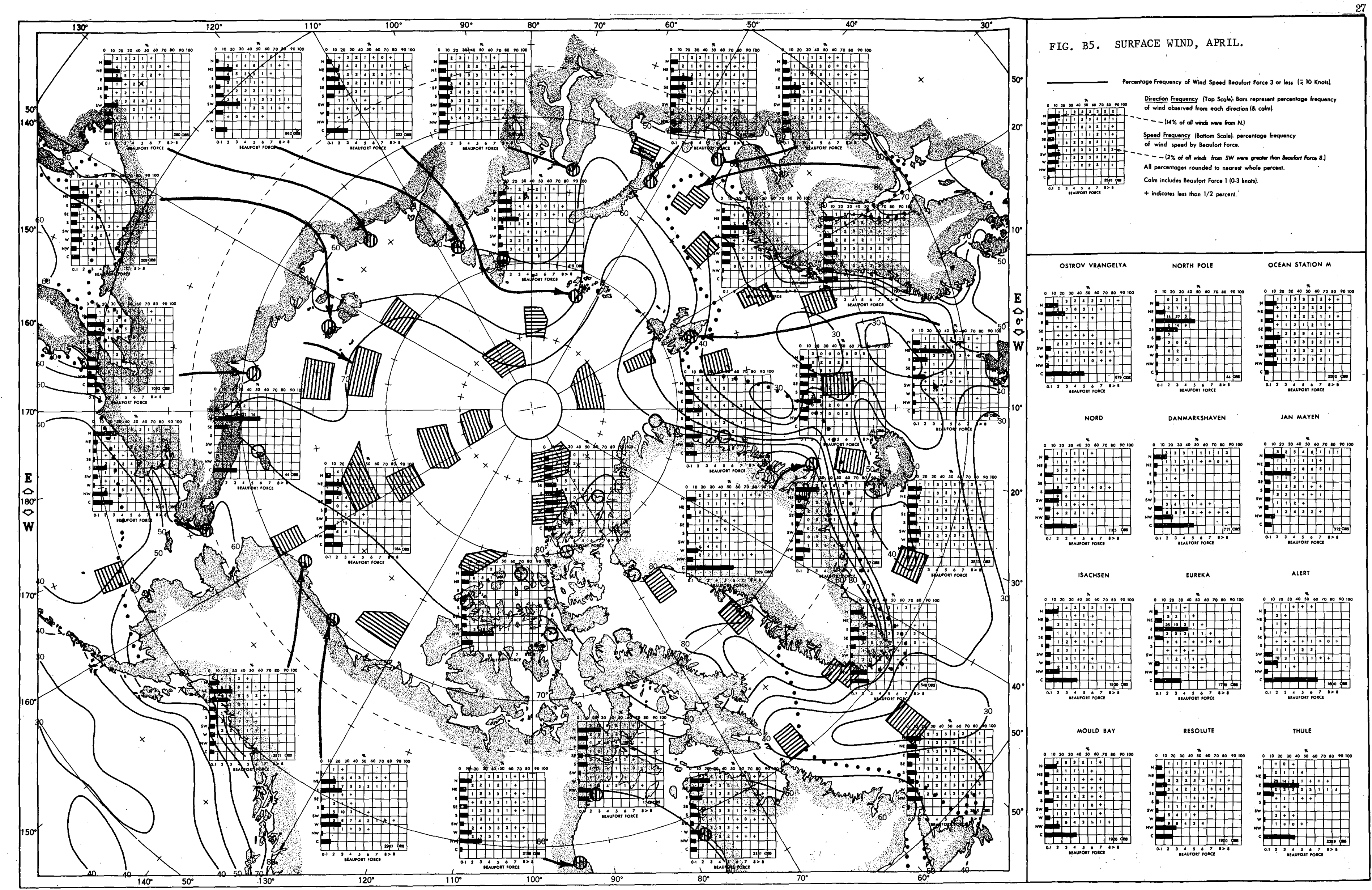




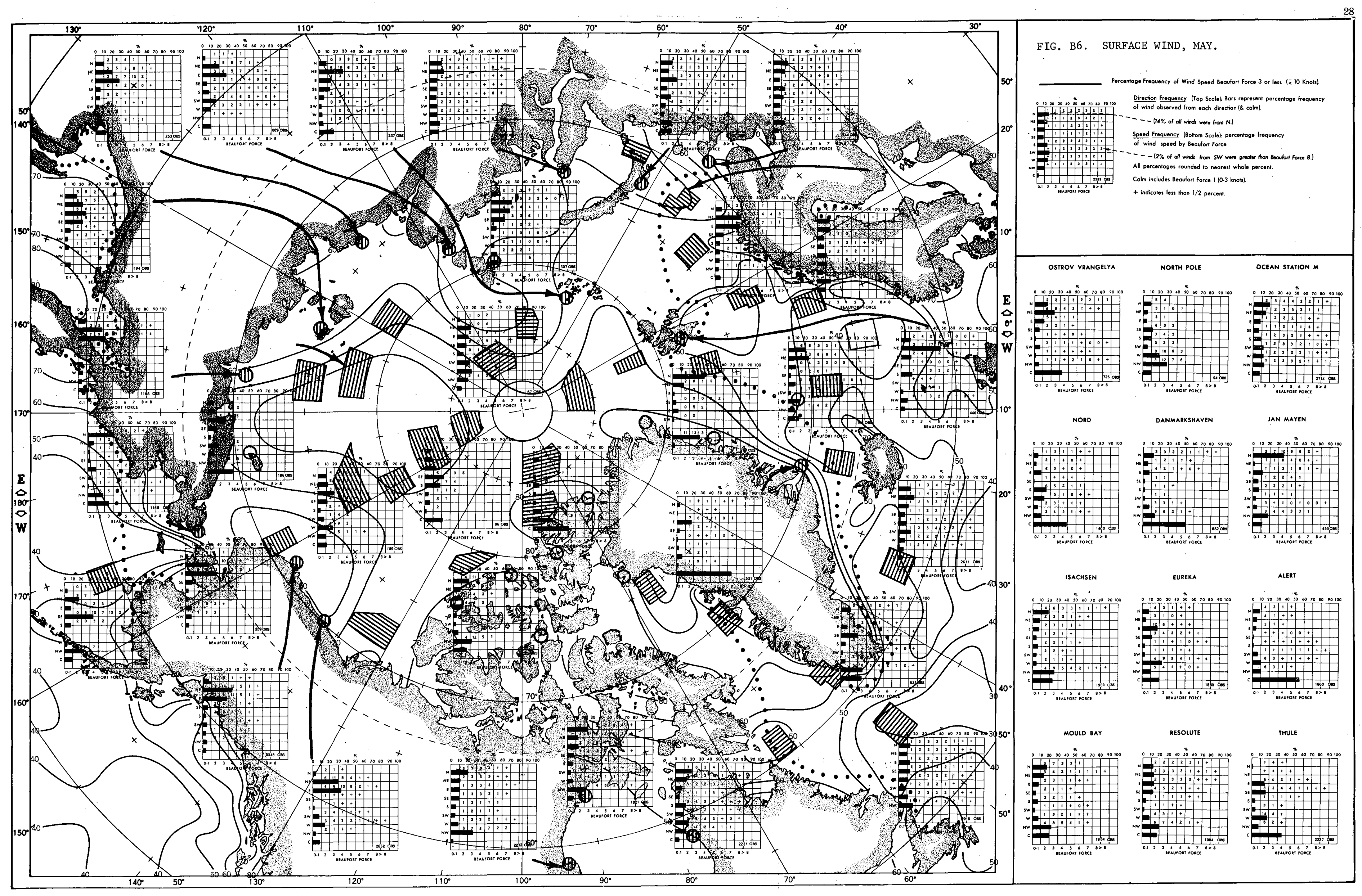




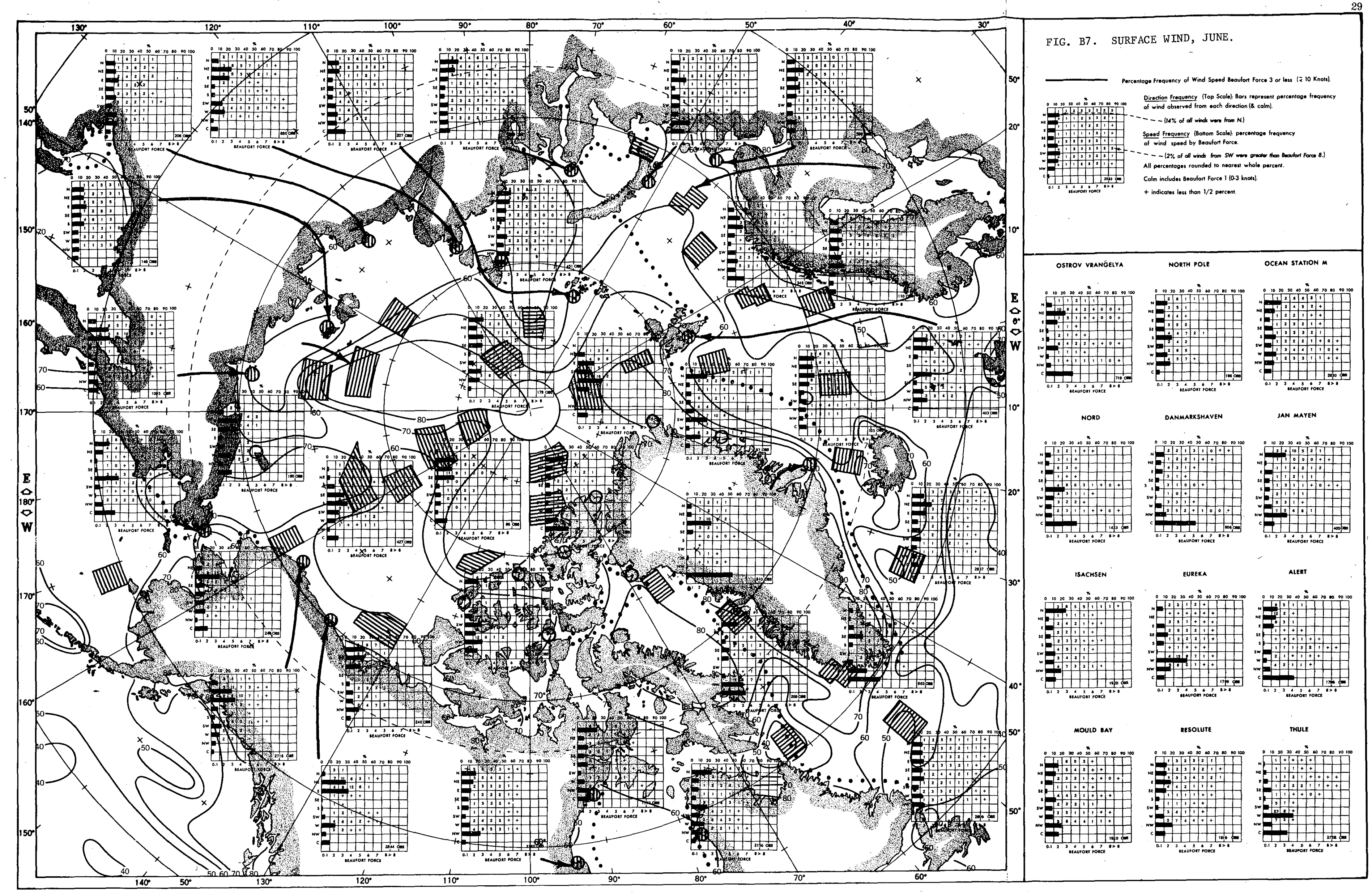




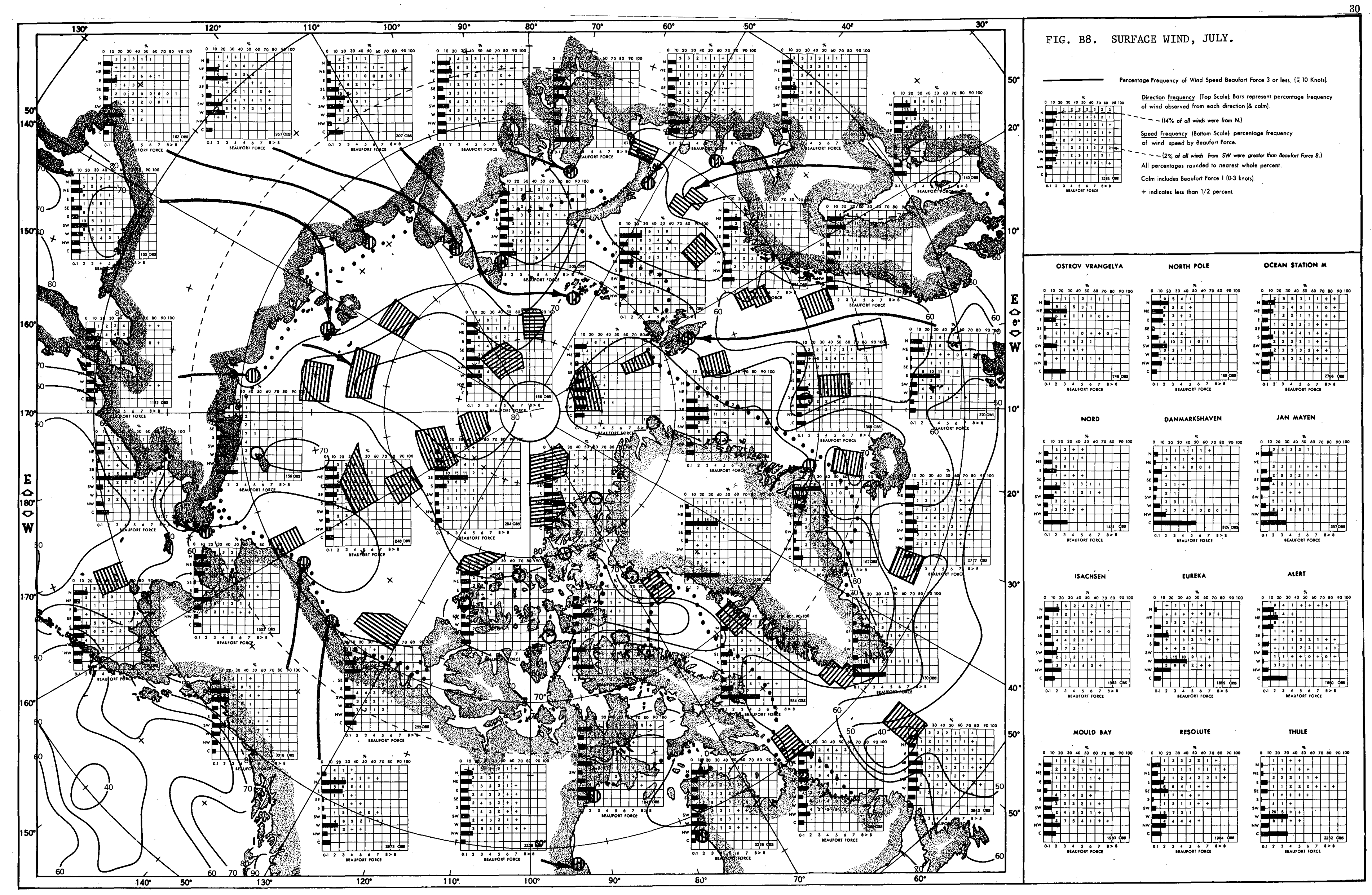




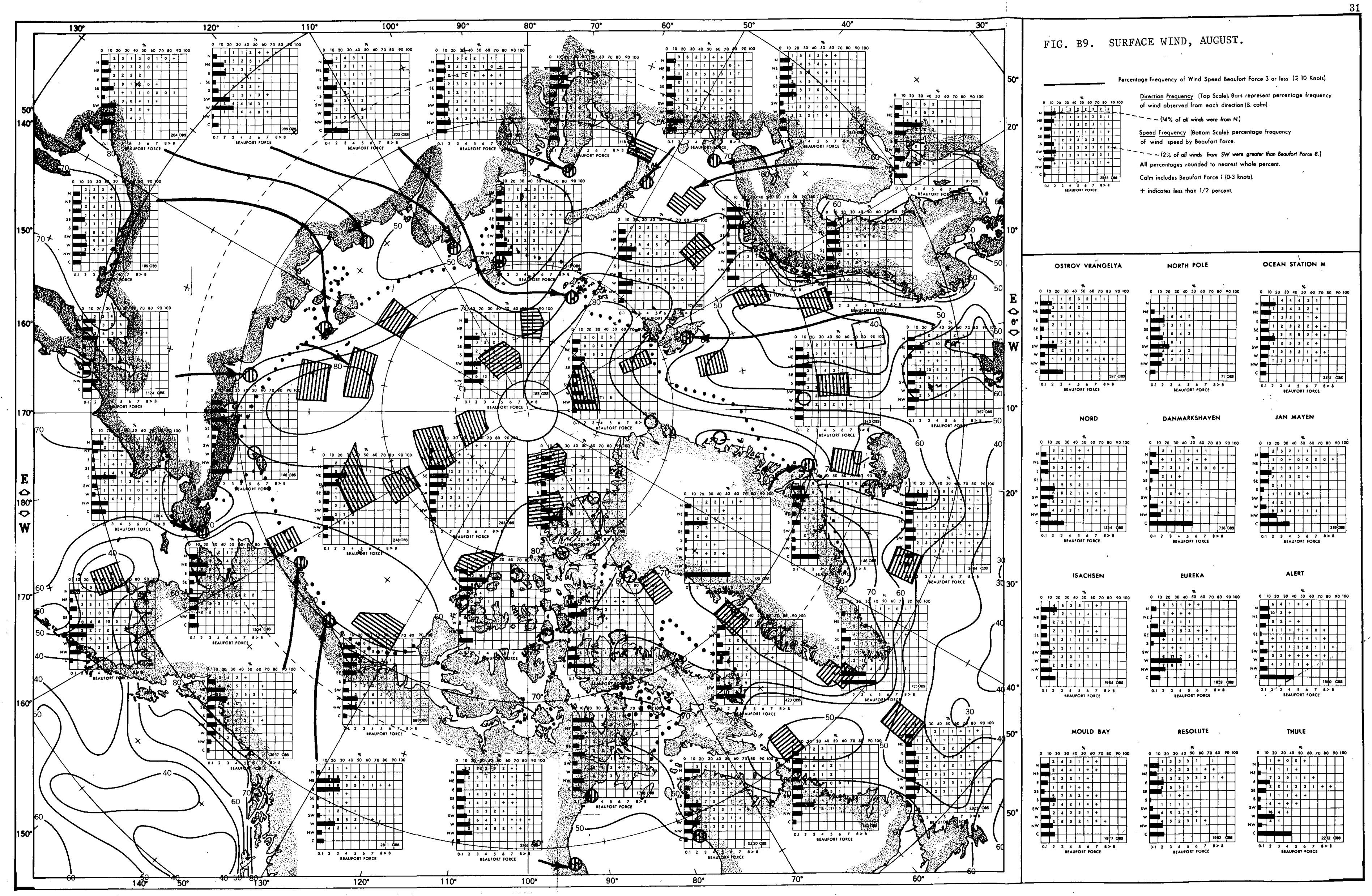




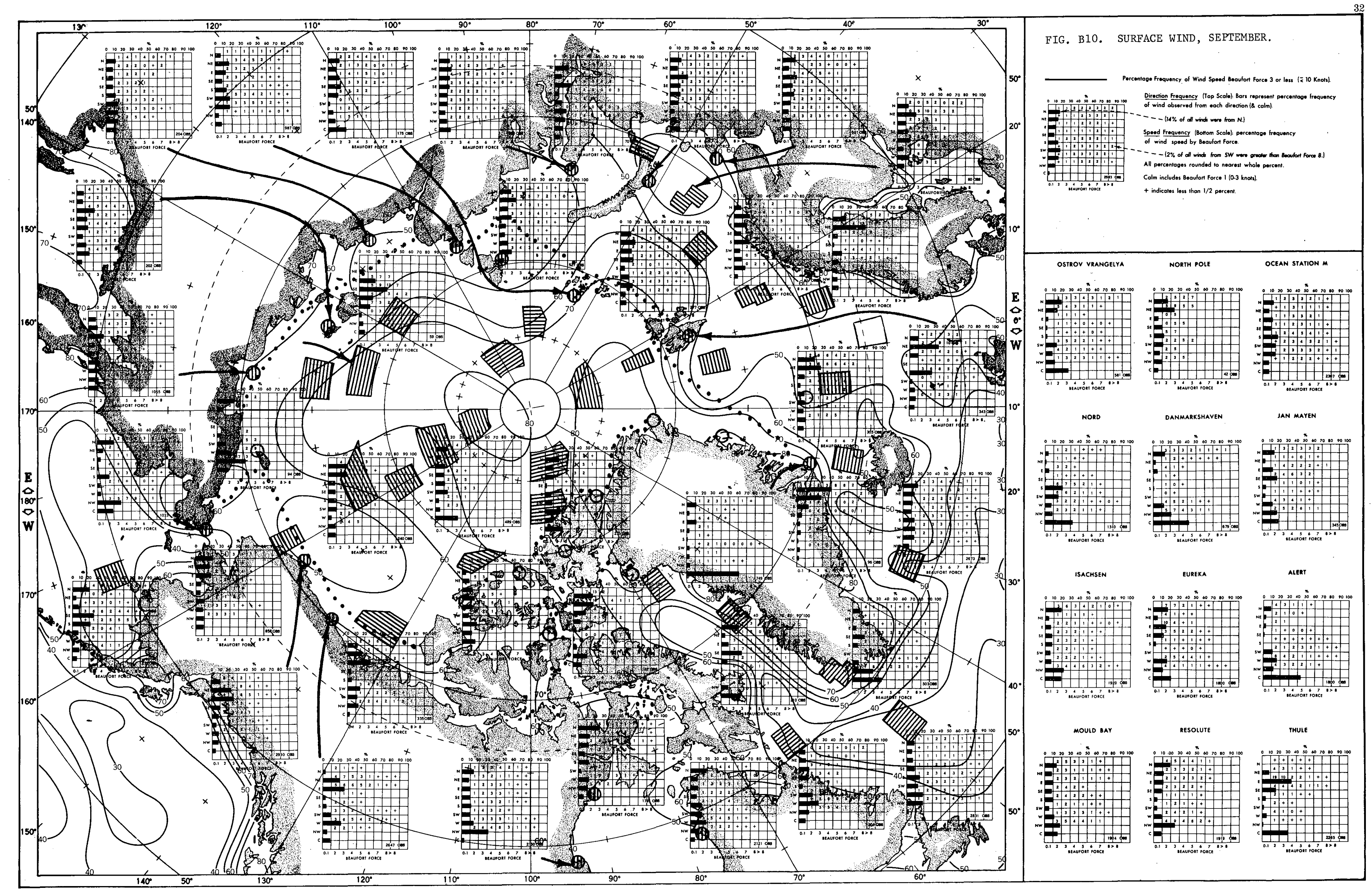




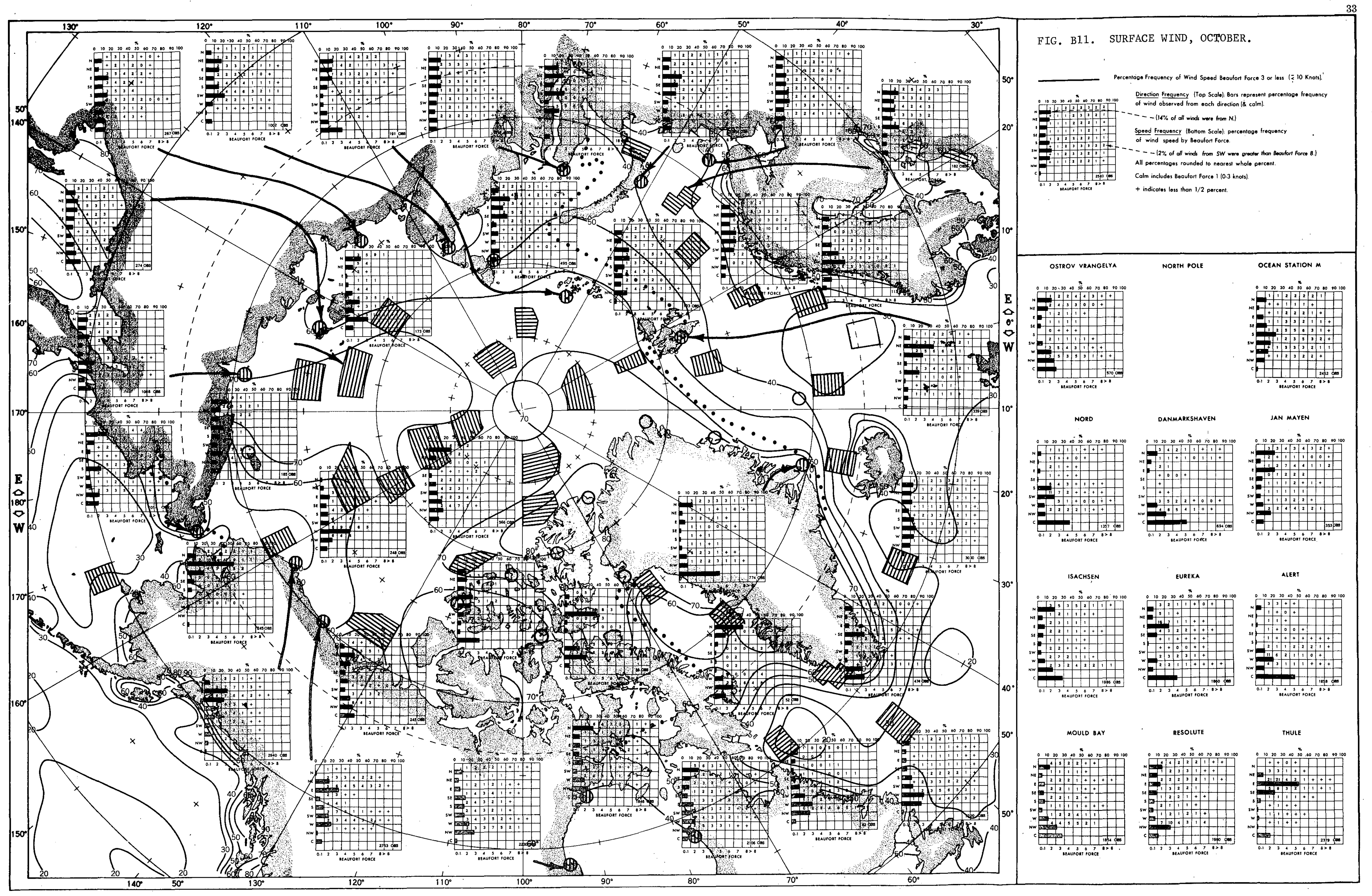




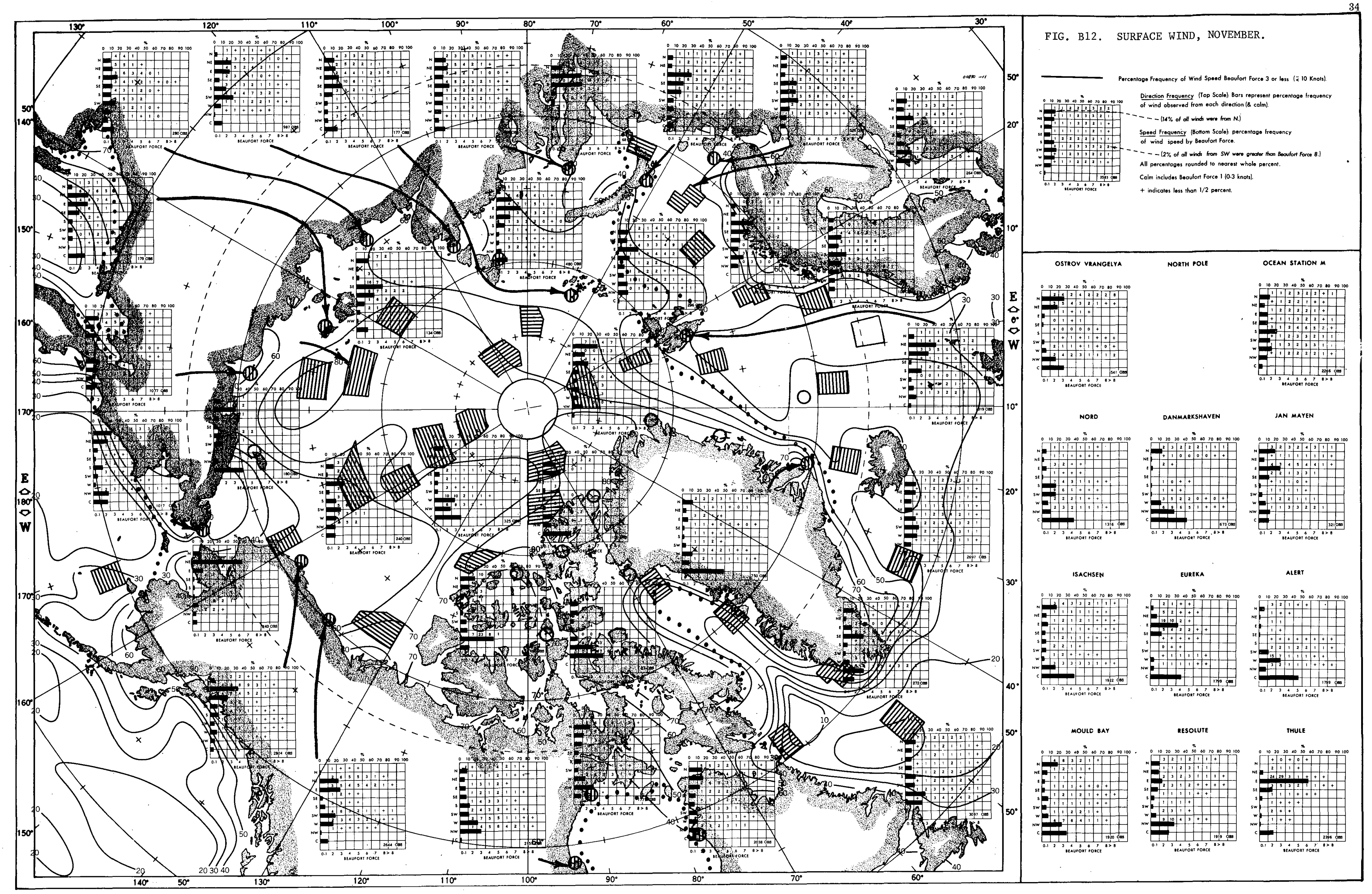




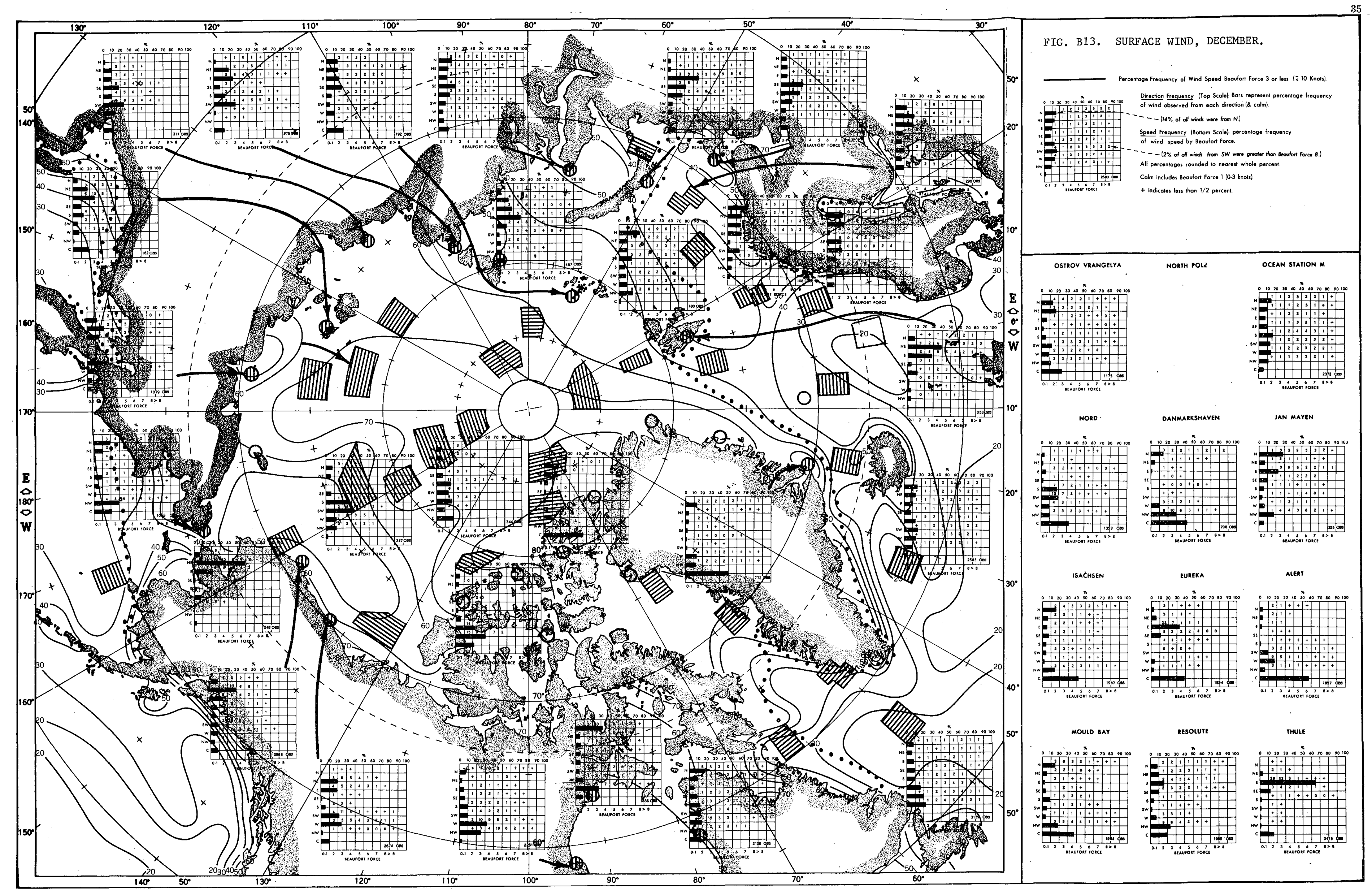

